The final publication is available at Elsevier via http://dx.doi.org/10.1016/j.erss.2018.06.011. (C) 2018. This manuscript version is made available under the CC-BY-NC-ND 4.0 license http://creativecommons.org/licenses/by-nc-nd/4.0/

Hot off the press! A comparative media analysis of energy storage framing in Canadian newspapers

By Sara Ganowski, James Gaede, and lan H. Rowlands

Published in Energy Research \& Social Science, Vol. 46, December 2018, pp. 155168. 


\title{
Hot off the press! A comparative media analysis of energy storage framing in Canadian newspapers
}

\begin{abstract}
Energy storage (ES) is a keystone technology for advancing low-carbon energy transitions, yet energy system change continues to be influenced by sociopolitical acceptance of emerging innovations such as storage. An initial Canadian contribution to the social-scientific study of ES, we conduct a comparative media analysis of news coverage on storage technologies in the provinces of Alberta and Ontario. Applying the Socio-Political Evaluation of Energy Deployment (SPEED) framework, we analyse representations of ES risks and benefits in 143 articles drawn from top-circulating Canadian newspapers between 2007-2017. We then evaluate frame and narrative trends describing ES in these provinces. In doing so, we identify: (1) a generally optimistic national perspective on ES, despite some regional variance in risk and benefit framing; (2) greater attention paid to high-profile, smaller-scale ES technologies; (3) a prominence of sustainability and transition narratives around ES; and (4) a positive temporal shift in ES discourse, reflecting changing regional energy priorities and Canada's increasing commitment to clean energy development. Our findings provide insight on interprovincial differences in social perception on ES and identify possible drivers for these variations to help inform future research, ES deployment and policy strategies in Canada and other evolving national energy markets.
\end{abstract}

Keywords: energy storage, energy transitions, media analysis, social acceptance

Funding: This work was supported by the Natural Sciences and Engineering Research Council of Canada (NSERC) as part of the NSERC Energy Storage Technology (NEST) Network (grant number 468468).

\section{Introduction}

Energy storage (ES) is expected to play a key role in the transition to a lowcarbon energy society [1-5]. ES refers to a suite of technologies (e.g. batteries, flywheels, pumped hydro, etc.) which can be used for storing and recovering electricity within a power grid (for useful processes at a later time) [6-9]. By providing grid balancing and power reliability services, as well as increased flexibility for renewable energy integration, ES can help enable cleaner, more reliable, and cost-effective electricity systems [1, 6-8]. As technology costs continue to decline (e.g. lithium-ion batteries) and ES use-cases expand across sectors, the global stoage market is expected to grow to US $\$ 90$ billion a year by 2025 [10] with over 50 GW of grid-scale deployments expected by 2026 [11]. Yet, global ES deployment to date has been slow, inconsistent, and geographically variable $[7,12]$. 
While leading national markets have begun to implement policies to support ES development (e.g. China, United Kingdom), many jurisdictions still lack the incentive or capacity to invest in storage deployment (e.g. Chile, Sub-Saharan Africa). Other regions, particularly in North America (e.g. Ontario, New York), are advancing ES innovations but remain deadlocked in R\&D phases due to contextual economic and regulatory barriers [10-11]. Canada's diverse energy and socio-political landscape, for instance, creates unique challenges for ES deployment [13-15]. In many provinces (e.g. New Brunswick, Ontario), technical developments are outpacing socio-political preconditions (e.g. regulations, public awareness) for project deployment and commercialization [15-17]. This misalignment is problematic, as energy technology deployment requires technical solutions to co-evolve consistently with market innovation, policy development, and social acceptance [18-19]. More broadly, the shift to a renewable energy economy is a complex socio-technical process involving both technological and socio-political reforms to dominant energy systems [19-22]. Energy transition progress thus requires careful consideration of often-over-looked social factors that influence technology and policy change, such as public perception and political will [20-24; 25-26]. Yet, while there is no shortage of techno-economic feasibility studies on new energy innovations $[1,25]$, there have been virtually no empirical assessments on the social dimensions of ES in Canada, or internationally [7].

National-level ES deployment will require a range of actors (e.g. generators, policy makers, end-users, etc.) to enable major alterations to existing energy systems (e.g. technology use, public consultation processes) [22-23, 27, 28]. Accordingly, as more ES installations are deployed across Canada, social processes such as public interest, acceptance, and dispute will have a steering influence on the technology's fate in society [7, 29-31]. Mass media will play a key role in this process, as they can radically influence decision-makers involved in the deployment of new energy technologies and policies [32-35]. Media coverage can not only demonstrate how key stakeholders are engaging with new ES applications but can also provide insight on how public discourse helps shape policy action across jurisdictions [25, 34]. Examining provincial-level media discourse on ES can thus help gauge social acceptance of the technology, while creating opportunities for more suitable deployment strategies $[7,25$, 34-39]. Given Canada's history with public opposition to renewable energy, recent provincial energy policy and market changes, and new government mandates for fossil fuel divestment, research on the social acceptance of ES is particularly timely $[5,7,16]$. 
In this paper, we apply Stephens et al.'s [25] Socio-Political Evaluation of Energy Deployment (SPEED) framework to the case of ES in order to explore how subnational socio-political factors influence energy technology deployment in a transition context [25, 34]. Using SPEED to examine ES media coverage in the Canadian provinces of Alberta and Ontario, we aim: (1) to examine how regional-level issue framing can both reflect and inform social acceptance of ES; (2) to consider how regional socio-political factors may influence ES deployment in Canada and other countries with fragmented and multi-level energy governance; in order to (3) elucidate opportunities for strategic ES policy and deployment in Canada, while (4) providing empirical groundwork for the social-scientific study of ES [7]. By combining SPEED with formative social acceptance frameworks [39-41], our exploratory study serves as an early response to recent calls for comparative analyses on ES [7], while contributing to a limited understanding of non-technical barriers to energy transitions [24-25, 42-43].

\section{Research case and design}

\subsection{The SPEED Framework}

The SPEED framework was designed as a comparative tool for examining how interacting socio-political factors influence technology deployment across varying geographic and institutional landscapes (typically at sub-national scales) [25]. When paired with media analysis methods, the SPEED framework can help uncover complex social processes (e.g. public risk perception) associated with energy system change, beyond the common technical and economic considerations that dominate policy decision-making [25, 29, 34-35, 38]. Accordingly, we investigate provincially-varying levels of ES social acceptance in two Canadian provinces through the lens of six SPEED categories (i.e. technical, economic, political, legal and regulatory, environmental and cultural) (see Appendix for the original SPEED framework [25, 34]).

By combining the SPEED framework with a frequency and narrative media analysis, we set out to answer: (1) how ES is generally perceived in provincial media coverage (i.e., whether positively or negatively framed and whether there are differences in perceptions of individual technologies); (2) what contexts or narratives media discussions of ES are taking place within, and whether these narratives differ in reflection of different socio-political underpinnings; and (3) how, if at all, representations of ES have evolved in response to major developments in provincial energy planning. In doing so, we contribute a new case study to SPEED literature in an effort to help support ES deployment processes, while advancing a transdisciplinary framework for assessing energy system change, in Canada and internationally. 


\subsection{Case selection and research scope}

We take a national focus on Canada recognizing its commitment to decarbonisation and expanding role in the global clean energy market [5], despite facing obstacles associated with a 'fragmented' national energy regime [44]. Canada's electricity generation, transmission and distribution falls primarily under provincial authority, which creates unique policy and economic challenges for consistent national clean energy development [44]. Nevertheless, the country's budding ES industry is among the fastest growing in the world. In addition to its expanding ES project portfolio [12], Canada's operational battery storage capacity is expected to account for 81 per cent of the total electricity storage market by the end of 2018 [45].

The country's diverse energy landscape and regionally-variable progress in ES deployment offers opportunity for rich comparative analysis and insight for other national ES markets with complex energy structures (e.g. United Kingdom, United States) [5, 45]. We chose to compare Alberta and Ontario as the provinces currently represent Canada's leading jurisdictions in ES development [15, 46-47], and have both recently implemented provincial energy plans for advancing storage. Despite their known history for achieving energy system change at different paces [44, 48-50], Alberta and Ontario are expected to be the first provinces to overcome economic barriers to grid-scale ES [15]. Still, both jurisdictions face considerable market, policy, and environmental constraints for large-scale ES deployment [46-47]. Regional energy politics, ideologies, and market evolutions will be particularly important to consider in provincial ES planning and development [50].

For instance, Ontario's 'hybrid' electricity sector (with its combined market and central planning features) and history of government intervention (e.g. from Progressive Conservative and Liberal governments) [49] continues to influence the uptake of provincial energy programs [49-50]. Likewise, Alberta's fossil fuel energy economy, Conservative political legacy and deregulated, wholesale electricity market will have unique implications for ES development [47, 49, 51]. Provincial progress in this context has already varied to date [5, 49]. Ontario's emission reduction strategy and 2014 coal-fired electricity generation phase-out have enabled significant lowcarbon energy deployment in recent years. By contrast, Alberta continues to be Canada's "fossil fuel powerhouse" with a longstanding investment in oil, and a coal phase-out not forecasted until 2030 [48, 53-54]. The provinces' markedly different energy market structures, and socio-political legacies suggest unique opportunities and barriers related to ES deployment (summarized in Table 1). Accordingly, the two cases 
provide ideal contexts for a SPEED analysis on how such dynamics may shape Canada's evolving energy industry.

Recognizing the early development stage of ES in Canada (and thus the public's limited exposure to specific ES technologies to date), we examine storage innovations in aggregate, rather than focusing on specific technologies. As such, our newspaper sample discusses ES both in concrete and conceptual contexts, including coverage of specific applications and experiences, as well as anticipated strategies and outcomes. While this is considered to be an acceptable approach for studying social dynamics of energy technologies [55], we recognize that various ES innovations possess diverse socio-technical characteristics and potentially distinct public acceptance profiles, salience, and associated narratives. Accordingly, as the ES market matures, and publics become more engaged with different applications, future research on this topic will help capture and distinguish these nuances.

\begin{tabular}{|l|l|}
\hline \multicolumn{1}{|c|}{ Ontario } & \multicolumn{1}{c|}{ Alberta } \\
\hline \multicolumn{1}{|c|}{ Provincial energy contexts and socio-political profiles } \\
\hline $\begin{array}{l}\text { Canada's second largest electricity producer } \\
\text { (over 90\% produced from zero-carbon sources) } \\
{[56]}\end{array}$ & $-\begin{array}{l}\text { Canada's third largest electricity producer (over } \\
90 \% \text { produced from fossil fuel sources) }\end{array}$ \\
$\begin{array}{l}\text { Unique 'hybrid' market structure and } \\
\text { diverse energy generation mix (e.g. } \\
\text { nuclear, hydro, wind, natural gas) }\end{array}$ & $\begin{array}{l}\text { Largest coal-fired power station fleet in the } \\
\text { country [53] }\end{array}$ \\
$\begin{array}{l}\text { National leader in wind energy } \\
\text { generation and clean technology } \\
\text { innovation [13-14, 15-17, 56] }\end{array}$ & $\begin{array}{l}\text { Currently deregulated, wholesale market } \\
{[48]}\end{array}$ \\
$\begin{array}{l}\text { Complex history with energy change } \\
\text { (e.g. high electricity prices, resistance to } \\
\text { renewable energy programs) [50] }\end{array}$ & $\begin{array}{l}\text { Fossil fuel dominated energy generation mix } \\
\text { (e.g. coal and coke, natural gas) with growing } \\
\text { wind, hydro and biomass production [53] }\end{array}$ \\
\multicolumn{2}{|c}{$\begin{array}{l}\text { Long history of energy market evolution (e.g. } \\
\text { transition from vertically integrated to } \\
\text { deregulated market) [48-49, 51] }\end{array}$} \\
\hline
\end{tabular}




\section{Energy policy, regulatory and market developments}

- Commitment to reducing fossil fuel use (e.g. 2014 coal phase-out, smart grid programs) [16, 48]

- Recent legislative amendments, renewable energy policies and regulatory changes (e.g. Ontario's Ministry of Energy 2012 Alternative Technologies for Regulation procurement; 2017 LongTerm Energy Plan) [13, 16]

- Various ES R\&D pilots, installation projects and emerging partnerships (e.g. Toronto Hydro pole-mounted ES system, Powin Energy to build Canada's largest ES project) [16]
2017 Renewable Energy Program introduced to support clean energy economy (e.g. competition to procure $400 \mathrm{MW}$ of renewable electricity capacity)

- 'Capacity market' planned for 2021 to help spur development of combined renewable energy and storage projects

Provincially-led clean technology R\&D efforts and rapidly expanding ES market (e.g. 'Alberta Innovates' 2014 call-for-proposals for ES projects; 2015 funding for battery and fuel cell projects designed to support grid-scale storage applications in the province) [48]

\section{ES opportunities and drivers}

- Current climate change targets and regulatory mandates (e.g. cap and trade, LTEP 2017)

- Rapidly growing contribution from renewable energy generation (e.g. wind, solar)

- Use-cases: addressing intermittent and surplus baseload generation issues, increasing renewable energy integration, providing frequency regulation, reactive power support and voltage control, and deferring major energy infrastructure investments [11]
Current climate change mitigation strategies (e.g. 2015 Climate Change Leadership Plan) and commitment to reducing reliance on fossil fuels (e.g. 2030 coal-phase out)

- Increasing grid enhancements designed for more diverse generation capacity [20]

- Use-cases: increasing remote connectivity, enhancing grid performance, addressing variable generation, optimizing transmission and distribution assets, 'firming' renewable energy capacity and reducing need for new fossil fuel infrastructure $[48,57]$

\section{ES risks and barriers}

- New potential costs within electricity system, tensions between rate classes, potential revenue instability for utilities (e.g. utility death spiral) and debates around stranded assets [13, 15, 54]

- Securing social acceptance of new energy projects (e.g. controversial history with resistance to wind development) [50, 58]
Lack of technical ES connection requirements on bulk system grid

- Uncertainties surrounding tariff rates in 'energyonly' market (e.g. generators are paid only for the electricity they provide to the grid) $[14,48]$

- Concerns around ES as a 'disruptive' technology, high project and operation costs, other regulatory barriers and technical uncertainties [48]

Table 1. Alberta and Ontario energy profiles. Comparison of provincial energy contexts, ES drivers and barriers. 


\section{Methods}

To conduct our SPEED-media analysis, we assessed the content and framing of ES discussions in news media coverage from 2007 to $2017^{1}$ in Ontario's and Alberta's top three most circulated (weekly) newspapers. In Ontario, these newspapers are The Toronto Star, The Toronto Sun, and The Hamilton Spectator. For Alberta, these newspapers are The Calgary Herald, The Edmonton Journal, and The Calgary Sun. All six newspapers report on regional and national topics related to business, politics, finance, sports and culture, with some difference in editorial stance, as depicted in Table 2 [59]. Circulation data for both sets of provincial publications are comparable given each jurisdiction's population size. For instance, The Toronto Star is the most circulated newspaper in the city of Toronto and the Greater Toronto Area, which has a population of over 6 million. Similarly, The Calgary Herald is the primary news publication within the city of Calgary, which has a population of 1.3 million [60]. We selected these six newspapers because they represent provincial-level public discourse that is produced and circulated both in print and digitally (e.g. online newspapers) within each jurisdiction, hence reaching a wide and relevant public audience. To supplement this data set, we also conducted a secondary national-level media analysis by selecting Canada's two national newspapers, The Globe and Mail and The National Post (Table 2). ${ }^{2}$

\begin{tabular}{|c|c|c|c|}
\hline Publication & $\begin{array}{c}\text { Weekly } \\
\text { circulation } \\
\text { (online } \\
\text { newspapers and } \\
\text { print media } \\
\text { combined) }\end{array}$ & News coverage focus & $\begin{array}{l}\text { Editorial } \\
\text { stance }\end{array}$ \\
\hline \multicolumn{4}{|c|}{ Ontario } \\
\hline The Toronto Star & $2,231,338$ & $\begin{array}{l}\text { business, politics, finance, } \\
\text { culture, sports, international } \\
\text { news }\end{array}$ & Left-leaning \\
\hline The Toronto Sun & 849,131 & $\begin{array}{l}\text { breaking local news, } \\
\text { government, business, culture, } \\
\text { sports, and art }\end{array}$ & Right-leaning \\
\hline $\begin{array}{l}\text { The Hamilton } \\
\text { Spectator }\end{array}$ & 681,451 & $\begin{array}{l}\text { business, finance, crime, and } \\
\text { local events }\end{array}$ & Centre \\
\hline \multicolumn{4}{|c|}{ Alberta } \\
\hline $\begin{array}{l}\text { The Calgary } \\
\text { Herald }\end{array}$ & 641,495 & $\begin{array}{l}\text { local news; business, politics, } \\
\text { crime, national and world affairs }\end{array}$ & $\begin{array}{l}\text { Centre to left- } \\
\text { leaning }\end{array}$ \\
\hline $\begin{array}{l}\text { The Edmonton } \\
\text { Journal }\end{array}$ & 555,252 & $\begin{array}{l}\text { regional news, business, } \\
\text { economics, finance, politics }\end{array}$ & Right-leaning \\
\hline
\end{tabular}

1 Data collected for first six months of 2017 only

${ }^{2}$ Circulation numbers reflect 2015 data provided by News Media Canada. News focus and editorial stances based on newspaper website information and Media Bias/Fact Check https://mediabiasfactcheck.com as of August 2017. 


\begin{tabular}{|c|c|l|l|}
\hline The Calgary Sun & 302,938 & $\begin{array}{l}\text { local affairs, business, culture } \\
\text { and entertainment }\end{array}$ & $\begin{array}{l}\text { Centre to right- } \\
\text { leaning }\end{array}$ \\
\hline \multicolumn{3}{|c|}{ National } \\
\hline $\begin{array}{c}\text { The Globe and } \\
\text { Mail }\end{array}$ & $2,149,124$ & $\begin{array}{l}\text { regional and national news, } \\
\text { economics, business, finance, } \\
\text { politics }\end{array}$ & $\begin{array}{l}\text { Left to centre- } \\
\text { leaning }\end{array}$ \\
\hline The National Post & $1,097,080$ & $\begin{array}{l}\text { National and international news, } \\
\text { government, politics, economics }\end{array}$ & $\begin{array}{l}\text { Right to centre- } \\
\text { leaning }\end{array}$ \\
\hline
\end{tabular}

Table 2. Newspaper data. Sampled newspapers, circulation and content information (2015).

We used the Factiva database (which provided access to all eight newspapers) to search for ES-related content that was published between January 1, 2007 and July 1, 2017. Since various terms are used to describe ES applications, we conducted multiple search queries to generate the broadest and most representative sample. The following algorithm was selected for each provincial search (with key terms appearing anywhere in the full article):

((energy storage or power storage or electricity storage) OR (flywheel or pumped hydro or flow battery or fuel cell or lithium-ion battery or thermal or lead-acid battery or compressed air or supercapacitor or superconducting or power-to-gas)) AND (project or facility or system)

To ensure only relevant articles were returned by Factiva, we included the search terms 'project,' 'facility,' and 'system' in our algorithm, as our scoping searches indicated the media's common use of these terms to describe ES deployments in an energy context. To capture provincial-level discourse, the 'Region' filter was set to each respective jurisdiction for both provincial and national newspaper searches. For example, to conduct the Alberta national newspaper search, we used the same search algorithm as the provincial search, while setting the 'Source' filter to 'Globe and Mail' and the 'Region' filter to 'Alberta.' This generated national newspaper articles published only in Alberta, thus reflecting provincial-level discourse. The same approach was taken for Ontario. We also adjusted our search criteria so that duplicated articles (e.g. wire stories) were not returned by the search.

We reviewed the search results to ensure articles discussed ES in an energy context, as well as to identify the extent to which each article focused on storage. Since our focus is on grid-scale ES (electrical and thermal-electrical systems), articles mentioning search terms without relevance to energy development were removed (e.g. 
ES discussed in medical or biological contexts). We also excluded discussions on electric vehicles (EVs), unless the articles examined EVs as part of integrated ES systems, where vehicles store and return electricity to power grids (e.g. 'power-togrid'). For instance, articles that focused solely on EV models or automobile battery parts were removed. To ensure these articles were not returned by the Factiva search, we excluded articles with industry and subject tags, 'motor vehicles,' 'automotive,' and 'car parts.'

Modifying the approach used by Langheim et al. [36] in their study of United States' smart grid media coverage, we organized the remaining articles into two categories: ES-Focused (ES-F) and ES-Subsection (ES-S), based on the extent of each article's focus on ES. ES-F articles were those that focused entirely on ES systems, technologies, legal processes, and/or markets, while ES-S articles were those that did not focus on ES exclusively but mentioned ES within a subsection of the article, as part of a broader energy development context.

To answer our research questions (Section 2.1), we used NVIVO $11.4^{\mathrm{TM}}$ to analyse, by province, (1) the salience and frequency of discussions on ES; (2) the types and frequency of frames used to describe ES risks and benefits; (3) the types and frequency of mentioned ES technologies; (4) the context in which ES is discussed (e.g. climate change); and (5) commonly used "industry buzzwords" describing ES. Using the SPEED framework, we analysed the framing of ES benefits and risks in all ES-F and ES-S articles. Specifically, we characterized the frequency of technical, economic, political, regulatory and legal, environmental, and cultural frames appearing in our data set (the results of which are summarized in Table 3). To further examine ES discourse (beyond risk and benefit framing), we conducted a narrative analysis by identifying frequent use of phrases and storylines describing ES development (e.g. 'innovation' and 'economic development') (see narrative code scheme in Appendix).

\begin{tabular}{|c|l|l|}
\hline SPEED Frame & \multicolumn{1}{|c|}{ Benefit } & \multicolumn{1}{|c|}{ Risk } \\
\hline & $\begin{array}{l}\text { Improves grid flexibility; allows } \\
\text { greater renewable energy } \\
\text { integration; increases energy } \\
\text { capacity; integrable into existing } \\
\text { infrastructure; applicable to other } \\
\text { sectors (e.g., transportation); } \\
\text { technology easily scalable; } \\
\text { Technical } \\
\text { relatively short project } \\
\text { development timelines; part of } \\
\text { 'smart grid' modernization }\end{array}$ & $\begin{array}{l}\text { Requires specialized skills and expertise; } \\
\text { lacking or unfavorable grid infrastructure } \\
\text { (e.g. Alberta's centralized grid); other } \\
\text { technical or logistical constraints (e.g. } \\
\text { geology); reliability and performance } \\
\text { concerns }\end{array}$ \\
& \\
\hline
\end{tabular}




\begin{tabular}{|c|c|c|}
\hline Economic & $\begin{array}{l}\text { Strengthens economy and fosters } \\
\text { growth (e.g., job creation, } \\
\text { training); opportunities for legacy } \\
\text { and new system actors (e.g. } \\
\text { increases competitiveness); cost } \\
\text { savings (utilities, infrastructure } \\
\text { upgrade deferral); cost savings } \\
\text { (end-user, time-shifting } \\
\text { consumption); optimization of } \\
\text { existing assets (e.g. renewable } \\
\text { and others) }\end{array}$ & $\begin{array}{l}\text { High costs outweigh benefits (e.g. } \\
\text { technology still cost ineffective); creates } \\
\text { new costs to actors within and outside } \\
\text { electricity system (e.g. transmission, } \\
\text { disruption to other industry supply } \\
\text { chains, fossil fuel industries); increases } \\
\text { economic and financial risks (e.g. } \\
\text { inadequate funding, investment } \\
\text { difficulties, market concerns, unclear or } \\
\text { lacking market rules, cost analysis } \\
\text { difficulties) }\end{array}$ \\
\hline Political & $\begin{array}{l}\text { Positive political ramifications } \\
\text { (e.g. fosters stakeholder } \\
\text { collaboration, strengthens } \\
\text { regional identity and energy } \\
\text { security); aligns with provincial } \\
\text { and national policy goals }\end{array}$ & $\begin{array}{l}\text { Negative political ramifications (e.g. } \\
\text { opposition to new policies, political } \\
\text { skepticism and contention); lacking } \\
\text { government support }\end{array}$ \\
\hline Regulatory and Legal & $\begin{array}{l}\text { Encourages new green energy } \\
\text { regulations and policies }\end{array}$ & $\begin{array}{l}\text { Lacking or unfavorable policies and laws } \\
\text { (e.g. building code restrictions); lacking, } \\
\text { underdeveloped, difficult or deadlocked } \\
\text { regulatory processes }\end{array}$ \\
\hline Environmental & $\begin{array}{l}\text { Climate change mitigation and } \\
\text { adaptation (e.g., reduces } \\
\text { emissions, facilitates } \\
\text { conservation and efficiency, } \\
\text { supports fossil fuel phase-out); } \\
\text { creates no or little harmful waste } \\
\text { (e.g. manufacturing processes) }\end{array}$ & $\begin{array}{l}\text { Potential threats to human and } \\
\text { ecological health (e.g. land use, resource } \\
\text { extraction) }\end{array}$ \\
\hline Cultural & $\begin{array}{l}\text { Encourages public support of } \\
\text { energy transition (e.g. less } \\
\text { NIMBYism than wind energy } \\
\text { development); strengthens } \\
\text { community sustainability, } \\
\text { engagement, and pride (e.g. } \\
\text { participation in ES projects, } \\
\text { services remote communities); } \\
\text { allows for positive energy } \\
\text { consumer behaviour change (e.g. } \\
\text { consumer empowerment, } \\
\text { agency, energy management) }\end{array}$ & $\begin{array}{l}\text { Invites public skepticism and community } \\
\text { opposition (e.g. concerns for impact on } \\
\text { way of life); cultural reluctance to } \\
\text { changing existing electricity system; may } \\
\text { prove difficult to influence consumer } \\
\text { adoption and behavior change }\end{array}$ \\
\hline
\end{tabular}

Table 3. SPEED analysis of ES in Canadian news media. Stephens et al.'s [25] SPEED

Framework applied to ES newspaper coverage in Alberta and Ontario (2007-2017).

\section{Assumptions and limitations}

We approach this research with the understanding that media play a dual role in both informing and reflecting the social acceptance of new energy technologies $[25,31$, 
34, 61]. Newspapers function as an important venue for public discourse, as people continue to rely on them to help construct their understanding of societal issues [6164]. Media content and framing analyses are thus useful for probing emerging social climates around new energy innovations and guiding energy decision-making [29, 32, 62]. This is not to say that media portrayal is an objective reflection of public opinion, [29], nor that the publications selected here represent the full breadth of Canadian public and media discourse on ES. We also note the difficulty of using the SPEED framework to capture all nuances of public framing of new technologies (i.e. how or why certain perceptions have come to exist) [29].

Nonetheless, we do not believe these to be major limitations to our study, as consulting provincial ES news coverage serves our objective for gauging initial public conversations on storage in an energy transition context within Canada. Further, the SPEED approach reflects an established, adaptable method for characterizing media distribution and framing of new energy technologies across various jurisdictions [25, 34]. SPEED media assessments can produce invaluable insights on public engagement with new energy innovations, from which policy makers and practitioners can draw as they seek to engage lay and expert stakeholders in energy development [29]. As such, our research aims to support more informed ES policy and deployment strategies that reflect stakeholder concerns and expectations (e.g. siting decisions, consultation processes) in Canada and elsewhere.

Additionally, we believe our comprehensive search criteria and diverse publication selection provide a representative sample of public discourse on ES in each province. While we recognize that other publications (e.g. small/local news outlets) may also contain ES discussions that could differ from those analysed here, our sample comprises a broad spectrum of the highest-circulated publications in each province (with diverse editorial stances), which can be considered most influential for informing social acceptance of ES. Finally, while we employ the common qualitative SPEED approach (similar to previously conducted smart grid [29] and carbon capture and storage assessments [35]), we encourage future research on the topic to consider the use of mixed-methods and disaggregated examinations of ES technologies in sociopolitical contexts. Combining qualitative framing analyses with statistical tests (e.g. ttests) could further ascertain the relationship between socio-political factors and social acceptance of certain ES technologies over others. 


\section{Results}

A total of 206 articles were retrieved from the provincial and national-level searches combined. We removed 63 irrelevant articles from this sample, as per our described criteria above, for a filtered total of 143 ES articles. This included 89 articles from Ontario, and 54 from Alberta. The Ontario search generated $31 \mathrm{ES}-\mathrm{F}$ articles and 58 ES-S articles, while the Alberta search generated 28 ES-F articles and 26 ES-S articles. Although there has been more ES activity in Ontario to date (e.g. operational ES projects, procurement), a greater ratio of ES-F articles appeared in Alberta articles. Notably, the Alberta sample contained more coverage on ES deployments occurring outside of the province (e.g. Ontario, Nova Scotia, California), which contributed to a higher number of ES-F articles. A summary of this dataset is included in Table 4.

\begin{tabular}{|l|c|c|c|}
\hline \multicolumn{1}{|c|}{ Newspaper } & $\begin{array}{c}\text { Total } \\
\text { number } \\
\text { of articles }\end{array}$ & $\begin{array}{c}\text { Total number } \\
\text { of ES-F articles }\end{array}$ & $\begin{array}{c}\text { Total number of } \\
\text { ES-S articles }\end{array}$ \\
\hline The Toronto Star & 49 & 22 & 27 \\
\hline The Toronto Sun & 5 & 1 & 4 \\
\hline The Hamilton Spectator & 4 & 1 & 3 \\
\hline The Calgary Herald & 17 & 10 & 7 \\
\hline The Edmonton Journal & 30 & 16 & 14 \\
\hline The Calgary Sun & 1 & 1 & 0 \\
\hline The Globe and Mail (Ontario) & 23 & 6 & 7 \\
\hline The National Post (Ontario) & 8 & 1 & 3 \\
\hline The Globe and Mail (Alberta) & 4 & 1 & 2 \\
\hline The National Post (Alberta) & 2 & 0 & 84 \\
\hline \multicolumn{1}{r|}{ Total } & 143 & 59 & \\
\hline
\end{tabular}

Table 4. Distribution of articles with varying focus on ES in newspapers. Total number of ES articles and sums of ES-F and ES-S in selected Canadian newspapers (2007-2017).

\subsection{Distribution of provincial ES media coverage over time}

While our Factiva search generated no clear aggregate trend for the frequency of articles mentioning ES between 2007-2017, there were some notable contrasts between provincial and national ES coverage. The highest numbers of articles were contained in the provincial newspapers, The Toronto Star (49) for Ontario and The Edmonton Journal (30) for Alberta, followed by national coverage from The Globe and Mail (27). The least amount of ES coverage was contained in The Calgary Sun (1) and The Hamilton Spectator (4). The annual frequency of ES-related articles increased steadily from 2007 to 2009, spiking in 2009, then falling and rising again in 2016 (see 
Figure 1). National newspapers presented a more recognizable trend, with The Globe and Mail articles increasing steadily from 2011 and peaking at 2016, suggesting a growing national interest in storage

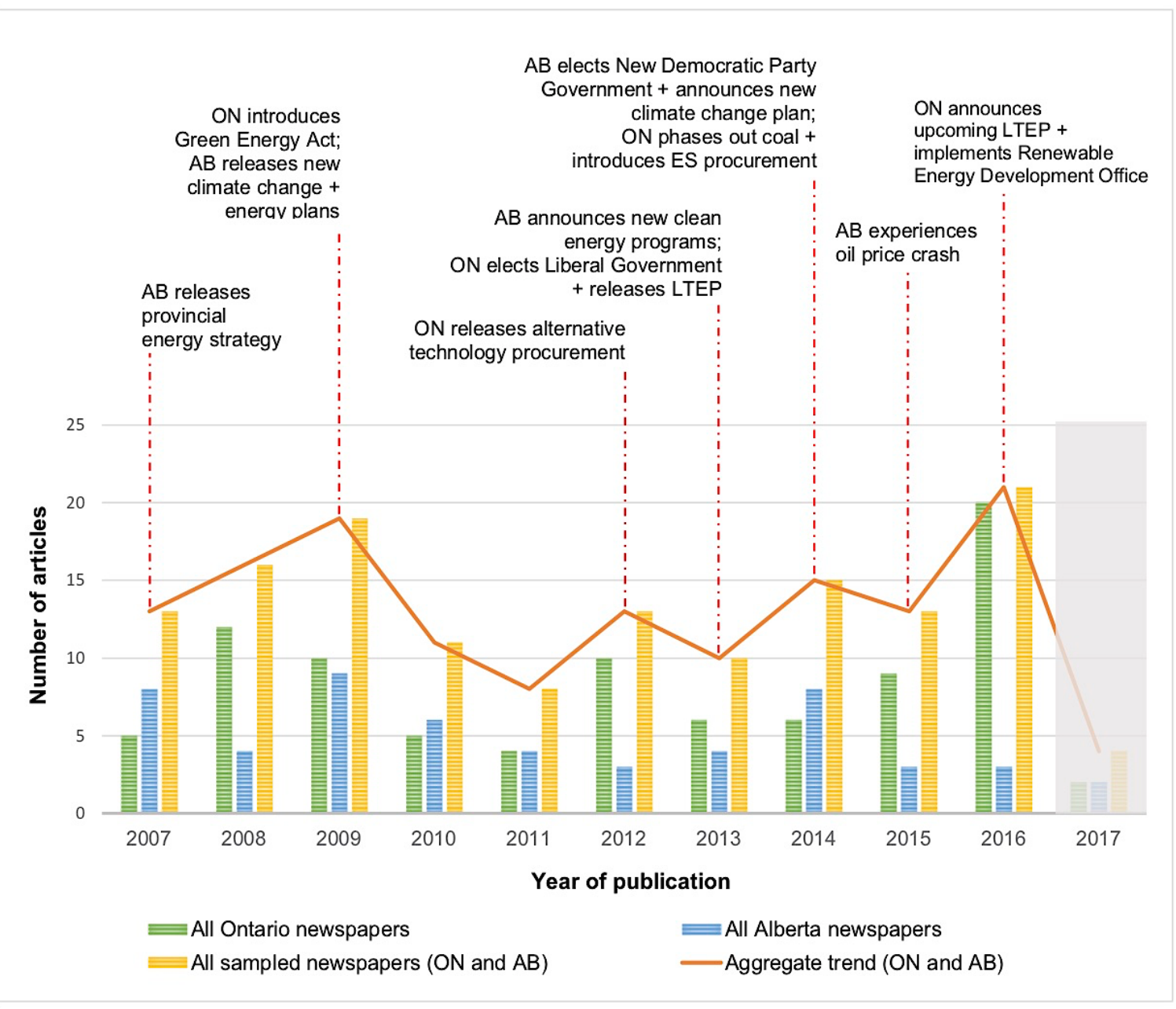

Figure 1. Distribution of ES media coverage in Canada over time. ES coverage in six provincial and two national newspapers: Ontario (ON) and Alberta (AB) (showing data until July 12017 ).

Provincial ES coverage was also considerably higher in 2008 (Ontario), 2009 (both), 2014 (Alberta) and 2016 (Ontario). Ontario articles published in these years often coincided with new policy developments, such as the 2009 Green Energy and Green Economy Act, which was designed to create "green" employment opportunities and support renewable energy development [46]. Increased government support around this time led to new energy deployments (e.g. wind turbines in Southwestern Ontario), which generated increased media coverage on policy, local opposition to projects, and debates around low-carbon technologies, including ES. Ontario ES discussions also rose again in 2012, with coverage dominated by The Toronto Star. These articles included debates on Ontario's electricity surplus, rate increases, and strategies outlined in the 2013 Long Term Energy Plan (LTEP). The following excerpt 
from The Toronto Star demonstrates how ES fit into discussions during these peaks:

"Lower energy demand as a result of a slowing economy, uncharacteristically warm winter weather, summer conservation efforts, rain-charged hydro resources, inflexible nuclear power stations, and intermittent wind resources all add up to more occurrences of power surpluses. Instead of paying other jurisdictions to take the excess power we generate, why not store it and use it for ourselves when we need it most?" - CEO of storage technology company [The Toronto Star, March 17, 2012].

ES discussions were especially prominent in The Toronto Star, which was the most responsive to provincial energy system changes within the decade. This contributed greatly to coverage peaks on ES since 2007. As such, removing The Toronto Star from the sample would have revealed a steadier growth trend in total media coverage on ES. Based on the political nature of Toronto Star conversations during this time, we anticipate that election years in Ontario might have also influenced the frequency of ES discussions.

In Alberta, The Edmonton Journal saw the greatest amount of ES-coverage (30), followed by The Calgary Herald (17), with the fewest articles contained in The Calgary Sun (1). The 2007 and 2009 article peaks in The Edmonton Journal and The Calgary Herald coincide with the introduction of several policy and regulatory strategies (e.g. Alberta's Provincial Energy Strategy, The Fair, Open and Efficient Competition Regulation). Our analysis below suggests that these provincial socio-political changes, amidst growing pressures for reducing fossil fuel generation (following Ontario's coal phase-out), may have led to increased media attention on ES. For instance, provincial Alberta ES articles peaked in 2014, following announcements of the incoming Climate Change Leadership Plan and new provincial funding for clean technology development (e.g. the ' $\mathrm{CO}_{2}$ Grand Challenge Competition' and the 'Alberta-Ontario Innovation Program') [14-15].

\subsection{SPEED Frames: Comparing perceived ES risks and benefits}

\section{Economic and technical frames}

Overall, ES benefits (positive framing) were mentioned more often than risks (negative framing) across all SPEED categories, with the exception of the Legal and Regulatory frame (10\% risks; $6 \%$ benefits) (Figure 2 ). Economic frames (57\% of all coded articles) and technical frames (50\%) dominated ES discourse across all newspapers. Technical benefits of ES were mentioned more than any other frame (risk or benefit), with $41 \%$ of all newspapers mentioning technical ES benefits (e.g. 
improved grid performance). Ontario articles often recognized protection against power outages, improved demand management, and overall grid optimization as key technical benefits of ES [e.g. The Globe and Mail, October 5, 2015]. Similarly, Alberta often recognized ES as a potential solution for addressing variable wind generation issues and reducing grid system failures [e.g. The Edmonton Journal, December 8 , 2014; The Edmonton Journal, March 4, 2015].

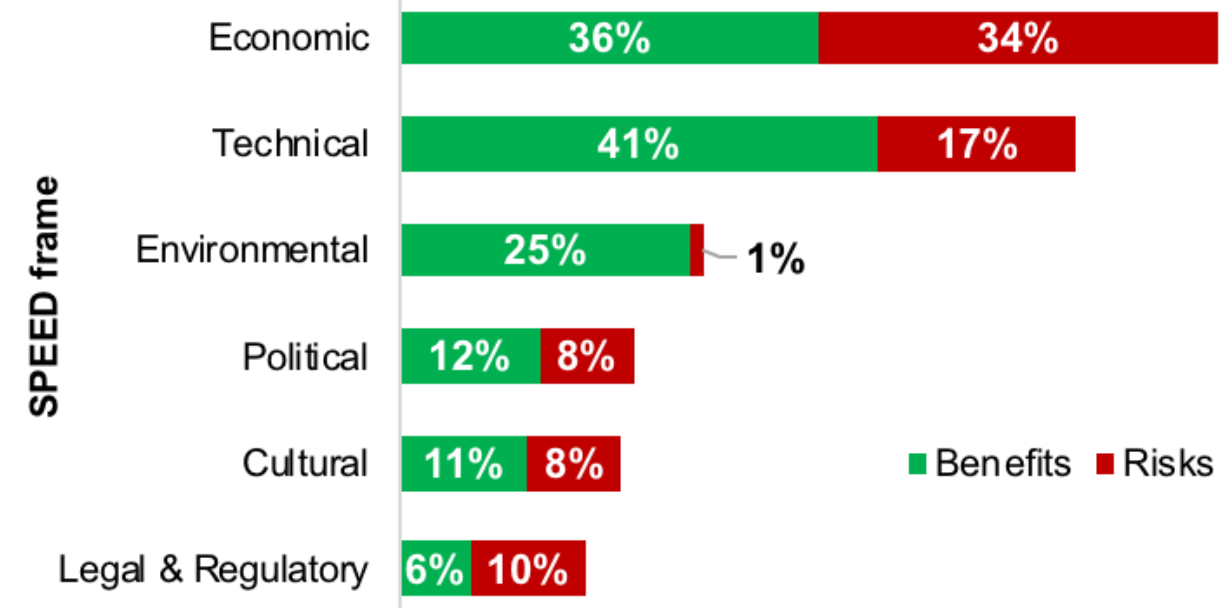

Percentage of articles

Figure 2. Alberta and Ontario SPEED frames. Total percentage of articles from all Alberta and Ontario newspapers mentioning SPEED risks and benefits (2007-2017) $(n=143)$.

The economic benefit frame was the second most common in our sample. In both provinces, these articles discussed ES as potentially strengthening the economy through creating new markets and job opportunities in clean energy sector. Coverage in both provinces also frequently discussed potential cost savings to the grid and increased efficiencies in electricity markets (e.g. greater returns on renewable energy investments). In Alberta, newspapers focused heavily on ES potential to strengthen local and remote community resiliency and create new business opportunities in the province's fossil fuel dominated energy market [The Edmonton Journal, August 27, 2008]. Ontario media focused more on cost and energy efficiencies, as well as increasing market competition for old and new participants introducing ES related services (e.g. utilities, start-ups) [The Globe and Mail, February 20, 2013]. 


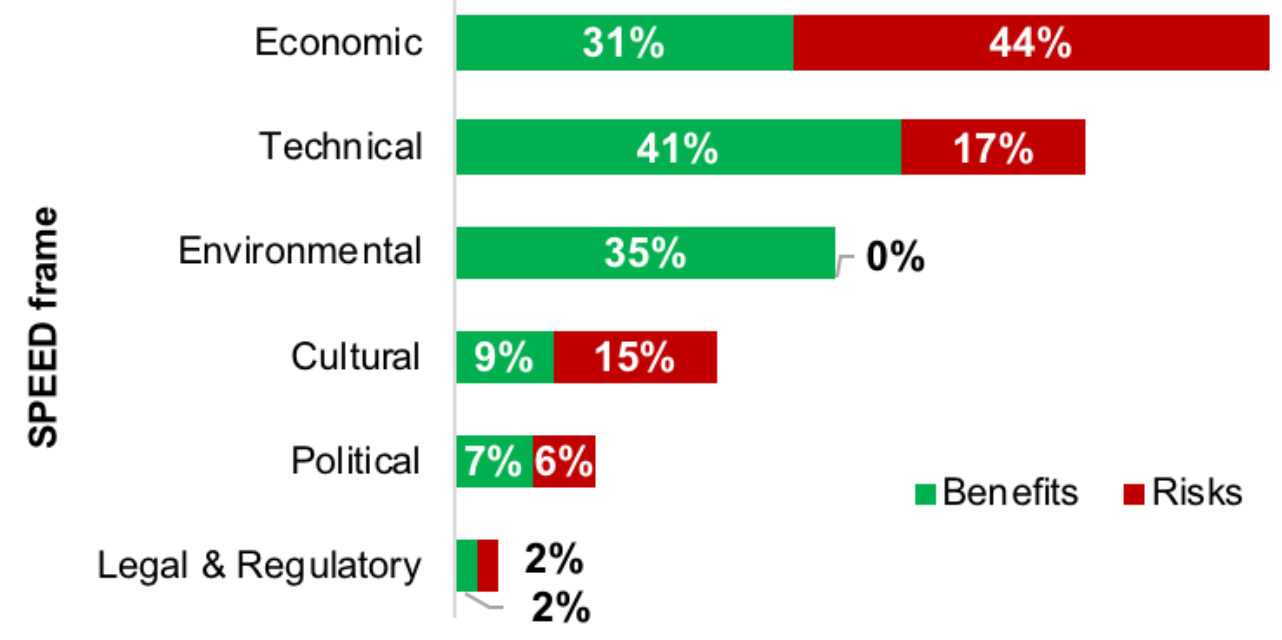

\section{Percentage of articles}

Figure 3. Alberta SPEED frames. Percentage of articles from all Alberta newspapers mentioning SPEED risks and benefits (2007-2017) $(n=54)$.

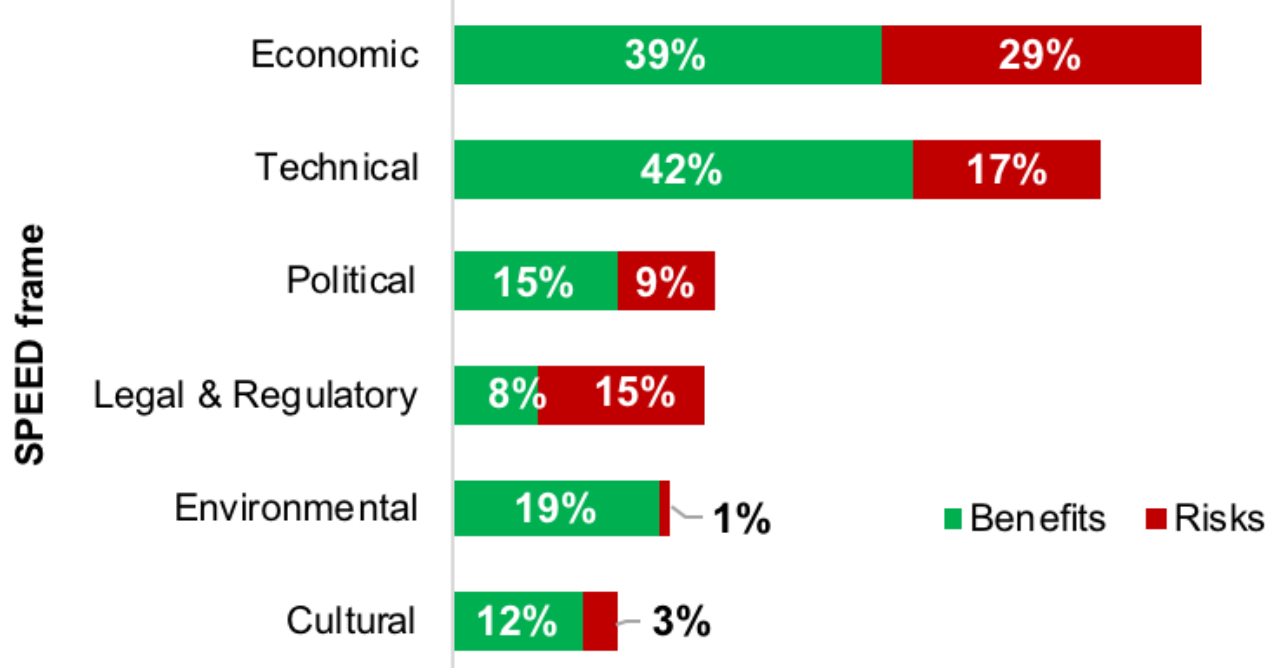

Percentage of articles

Figure 4. Ontario SPEED frames. Percentage of articles from all Ontario newspapers mentioning SPEED risks and benefits $(2007-2017)(n=89)$.

The Ontario sample $(n=89)$ recognized more economic ES benefits $(39 \%)$ than it did risks $(29 \%)$. In contrast, the Alberta sample $(n=54)$ contained more economic risk statements (44\%) than benefits (31\%) (see Figures 3 and 4 ). The benefit-to-risk ratio for economic framing across all coded articles (Alberta and Ontario) was approximately 1:1. Economic risks in Alberta articles focused on high technology costs, unfavourable economics, and potential threats to fossil fuel and other industry supply chains. For 
example, growing production of ES batteries is said to increase global lithium demand (approximately $73 \%$ by 2025 ), creating supply disruption concerns for power electronics and resource extraction sectors [The Edmonton Journal, March 18, 2017]. Alberta also viewed ES as a risk to the province's 'oil patch,' as a result of increased competition for capital spending and decreasing reliance on fossil fuel production. Overall, economic-risk articles in Alberta described ES commercialization as a longterm, costly venture with long-pay back periods.

Economic risks in Ontario articles discussed the implications of future disinvestment in nuclear energy (e.g. revenue and job losses), resulting from growth in ES and other distributed energy resources. These articles often discussed storage as a 'disruptive technology' that could lead to financial losses for other electricity system actors. Ontario's utilities, for instance, could bear the greatest costs, as ES development may lead to stranded transmission assets and customer defection [5] [The National Post, April 1, 2016; The Globe and Mail, January 2, 2007]. Coverage on this potential outcome included concerns about possible electricity price increases, particularly as utilities struggle to implement new business models for ES services. Other Ontario economic risk articles focused on barriers for future market growth of ES, such as financing challenges for developers and unclear and/or non-existing market rules [The Toronto Star, February 18, 2012].

\section{Environmental frames}

Environmental framing was common in both jurisdictions. Approximately $25 \%$ of all coded articles recognized environmental benefits of ES, such as its ability to help "offset emissions from current oil sands developments" and other fossil fuel production [The Edmonton Journal, March 4, 2015]. Over one-half of the environment benefit framings discussed ES in the context of provincial plans to 'phase-out' fossil fuels in an effort to transition to a low-carbon economy. These conversations were surprisingly more common in Alberta articles, which often grouped ES with wind development and 'coal phase-out' plans as "low-hanging fruit on a list that would put the province on a lower-carbon path" [The Calgary Herald, May 11, 2017; see, also, e.g. The Edmonton Journal, December 8, 2014]. Such articles also discussed how major fossil fuel market players (e.g. TransAlta) have "started to dabble in energy storage" in support of the province's "bold" Climate Change Leadership plan - which, as one writer noted, is "something that would have been unthinkable less than a year ago [2014], in a province that wears its fossil fuel heritage with pride" [The Calgary Herald, May 11, 2017]. 
Similarly, Ontario articles suggested that baseload power from nuclear plants can be economically replaced by 2020 with a combination of ES and renewables [The Toronto Sun, May 31, 2016], advocating for technologies such as pumped hydro storage to "replace the use of coal and natural gas on the grid" [The Toronto Star, September 17, 2007]. The benefit-to-risk ratio of environmental framing across all coded articles was 36:1, as only one ES-related environmental risk was mentioned in the sample (see Table 3 for SPEED framework and risk-benefit results).

\section{Political frames}

Minimal political discussions in Alberta likely reflect limited policy development and less government intervention in the province's energy sector in relation to Ontario. Still, most Alberta political risk-oriented articles revealed tensions over ES investment decisions, as the provincial government has only recently become more supportive of allocating capital to clean energy development while expensive "mega-projects" in the province's oil sands continue to demand funding [The Edmonton Journal, July 8, 2014].

In contrast, approximately $24 \%$ of all Ontario coded articles contained political framing, which generally revealed contentious debates around provincial energy issues. ES appeared within wider discussions around costs incurred from the province's past renewable energy investments, stranded debts from nuclear contracts, increasing electricity rates, and recent cap-and-trade schemes [The Toronto Sun, May $31,2016]$. At the same time, some Ontario articles also anticipated political benefits of ES, such as its potential reconcile controversies around provincial energy issues by improving industry and government collaboration in order to meet clean energy targets [The Globe and Mail, December 22, 2016].

\section{Cultural frames}

Contrasts in provincial discourse were also reflected in cultural framing. For example, the cultural benefit-to-risk ratio in the Ontario sample was $3: 1$, while Alberta's ratio was 1:2. Ontario focused more on the potential of ES deployment to improve standard of living and stimulate positive community and consumer engagement in energy development, while Alberta articles showed concern over potential threats that storage and other clean technologies could pose to familiar energy consumer practices, traditional ways of life (e.g. health, trade employment), and contained general skepticism of the feasibility of ES in the province.

\section{Legal and regulatory frames}

Legal and regulatory framing varied considerably between the provinces. 
Ontario saw a benefit-risk ratio of approximately $1: 2$, which represented $20 \%$ of all coded Ontario articles, while Alberta had a ratio of 1:1, but this represented less than $4 \%$ of the provincial sample. A higher frequency of Ontario discussions within this category was expected, given recent regulatory developments in the province, including its $50 \mathrm{MW}$ ES procurement process [16]. Still, Ontario articles that stated legal risks stressed that existing regulatory constraints must be overcome to facilitate successful ES integration [The Toronto Star, February 18, 2012].

Overall, frequencies of ES risk and benefit SPEED framing in Alberta and Ontario newspapers also indicated a stronger social acceptance of ES in later media discourse (i.e., 2011-2016), which focused on the benefits of ES, while earlier discourse (i.e., 2007-2010) was more risk-oriented. For instance, mention of ES benefits in Ontario peaked in 2016, which contained 21 total references to storage benefits (from the $18 \mathrm{ES}$ articles published that year), while mentions of ES risks within the same year were considerably lower (6 references). This revealed a total benefit-torisk ratio of 7:2 (across all SPEED categories) in Ontario ES coverage in 2016, indicating a slight decrease in risk perception of ES from the 7:3 ratio in 2007. However, a stronger change in perception was observed in Alberta during this time, which revealed a total benefit-to-risk ratio of 2:1 in 2007 and 4:1 in 2016 .

\subsection{Types and frequency of mentioned ES technologies}

We found a relatively diverse representation of ES technologies in all sampled newspapers (see Figure 5), with most articles mentioning numerous technologies. Fuel cells and batteries (e.g. flow and lithium-ion) were most frequently discussed (both mentioned in approximately $25 \%$ of all coded articles), while ultracapacitors and powerto-gas technologies were least mentioned $(<4 \%)$. Varying provincial market structures, regulatory conditions, and environmental suitability, may have influenced the types and frequency of technologies mentioned. For instance, Alberta revealed a strong interest in thermal and hybrid-solar ES applications, likely due to the province's high energy demand in the winter, decreasing solar technology costs, and abundant solar resource in its southern region [The Globe and Mail, April 22, 2014]. Similarly, batteries (mentioned in approximately $30 \%$ of all Ontario articles) appeared to be more economical for small-scale applications, while pumped hydro and compressed air applications were described as better suited for bulk storage on Ontario's geological landscape (e.g. salt caverns, hydropower infrastructure). Nonetheless, discussions on large-scale ES systems, particularly in Alberta, were less prominent than smaller-scale 
and earlier niche technologies (e.g. Tesla batteries).

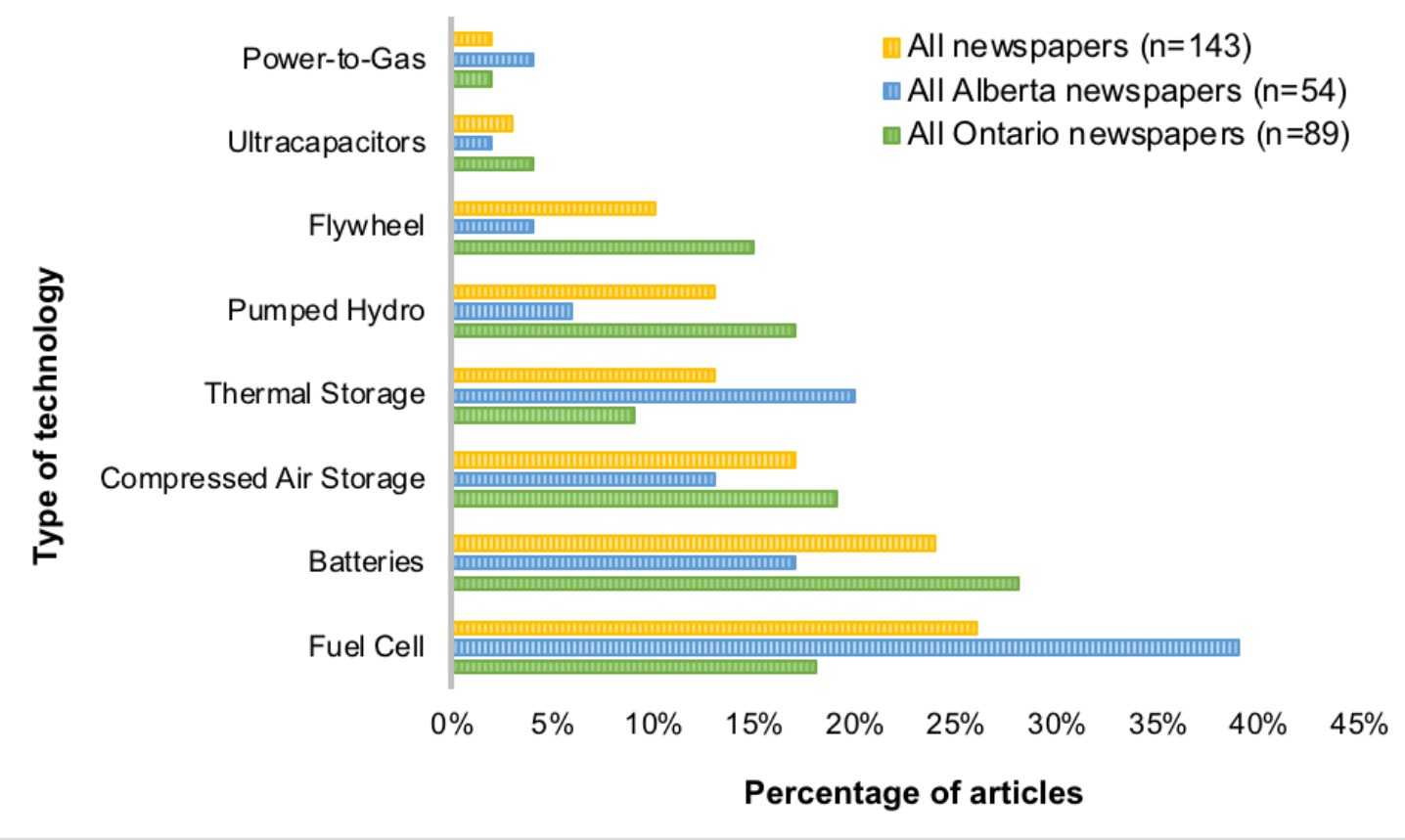

Figure 5. ES Technologies. Percentages of articles in all sampled Canadian newspapers mentioning specific ES technologies (2007-2017).

\subsection{Narratives in ES discussions}

In addition to our SPEED assessment, we categorized articles into specific 'narratives' (i.e. themes, storylines). Seven such narratives were identified: (1) economic development; (2) climate change and decarbonisation; (3) energy transitions and system change; (4) policy and governance; (5) technological innovation; (6) community development and infrastructure; and (7) transportation (Figure 6). We identified these narratives through a combined inductive and deductive coding process, wherein themes were considered 'common' if they arose within the data set five or more times and/or aligned with the six SPEED frames. For instance, articles coded with the 'economic development' narrative included SPEED economic risk and/or benefit statements, and generally discussed ES in a market development or finance context. Similar to our SPEED analysis, some articles reflected more than one narrative, describing ES for instance, as a climate change mitigation tool that could stimulate growth in other sectors.

The 'economic development' narrative was the most common in all newspapers, occurring in approximately $75 \%$ of all coded articles. The 'climate change' narrative occurred in $72 \%$ of all coded articles, and the 'energy transition' narrative was 
identified in over $55 \%$. The 'transportation' narrative (7\%) was the least popular, though this was likely due to our search exclusion of EV-related articles.

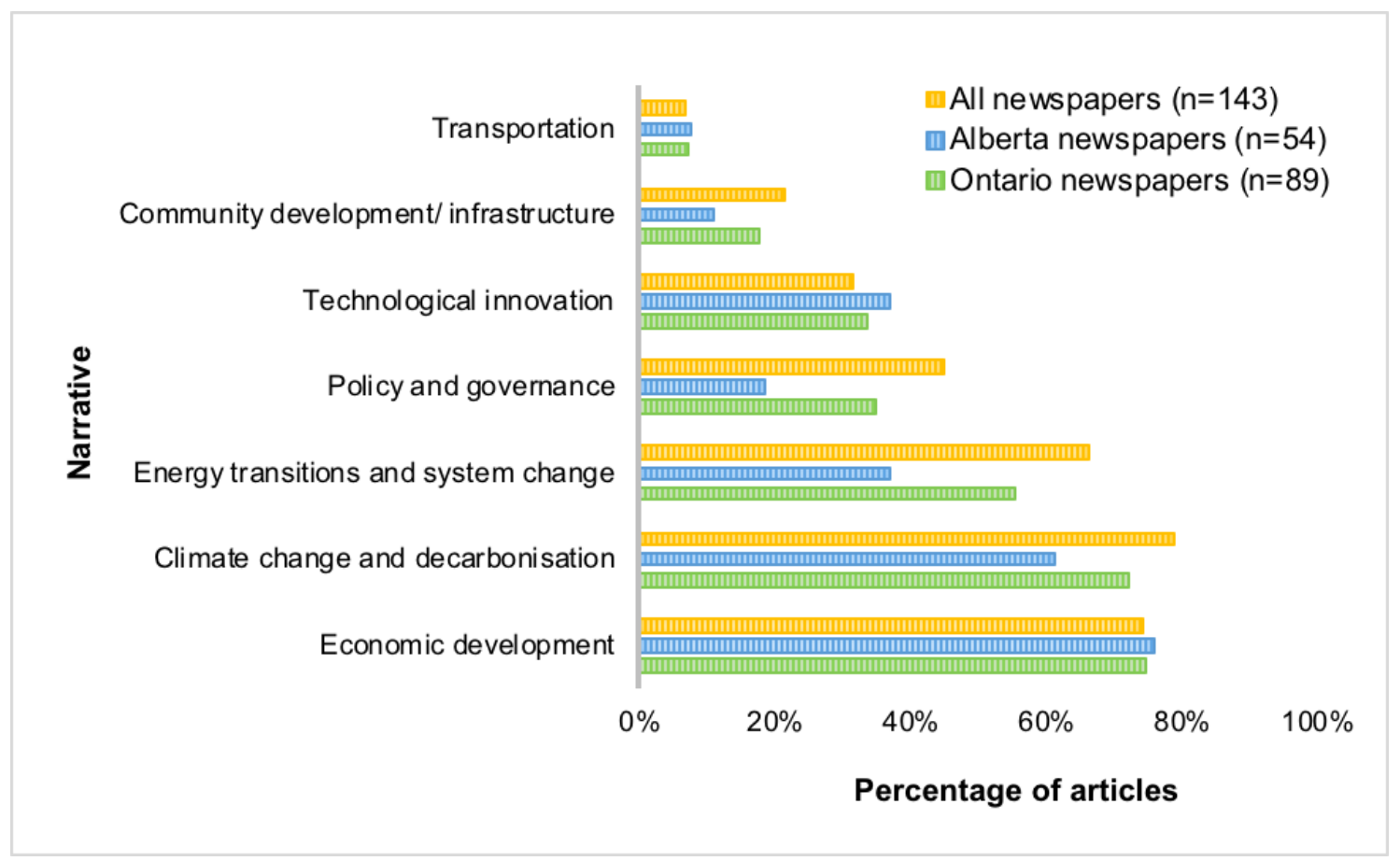

Figure 6. ES Narratives. Percentages of articles in all sampled Canadian newspapers discussing ES in various contexts (2007-2017).

Narratives also varied across the jurisdictions. Overall, Ontario yielded more positively framed 'economic development' discussions around ES. In contrast, earlier Alberta articles revealed greater scepticism around ES as a feasible alternative to fossil fuel generation, with many arguing that oil and gas will continue to "play a big role in the new energy era" [The Edmonton Journal, July 11, 2009]. Likewise, the 'transition' narrative was more prominent in Ontario articles, of which $66 \%$ focused on ES as a component of energy system change (e.g. fossil fuel phase-outs, smart grid deployment, improved demand management). Comparatively, 37\% of Alberta articles discussed ES in a transition context, wherein the use of ES as a 'system change' tool was recognized but stated less explicitly or even debated. The 'policy and governance' narrative was also more common in Ontario articles (45\%) than in Alberta articles (19\%). However, earlier Ontario discussions focused on green policy debates and clean energy scepticism, while later discourse generally identified ES as a promising strategy for meeting emissions targets. Alberta and Ontario articles contained similar discussions on ES as a symbol of technological innovation, reporting on R\&D, most of which is currently based in Ontario. Finally, both provinces also demonstrated a 'community' narrative which discussed ES in relation to urban planning, city 
infrastructure, and other community-focused topics (e.g. citizen engagement) [The Globe and Mail, October 5, 2015].

\subsection{Industry buzzwords}

Within the narratives discussed above, we also identified specific language used to describe ES in news media, particularly by industry actors (e.g. developers, utility executives). This dialogue included industry buzzwords that provided further insight on social perceptions of ES in media. For instance, approximately $20 \%$ of all coded articles referred to ES as one or more of the following terms (in order of frequency): (1) the holy grail; (2) a game changer; (3) a disruptive technology; (4) a transformative technology; and (5) the missing link (e.g. to achieving a low-carbon economy) [The Edmonton Journal, October 15, 2014; The Toronto Star, September 22, 2012]. These terms primarily appeared in articles which reflected the 'energy transition' narrative, wherein each phrase was used to describe the potential of ES to support an evolving energy system. Over $80 \%$ of these articles, however, were published in Ontario, which was more explicit in describing ES as the "missing link" [66] to clean, reliable energy systems [66]. A quote from an article in The Globe and Mail (Ontario) provides an example of the use of these buzzwords:

\footnotetext{
"Companies across the world are racing to commercialize a wide range of storage technologies: from modern flywheels to compressed air storage to dozens of advanced battery types. Those innovations will not only improve the economics of intermittent sources such as wind and solar, they could provide competition to natural gas-fired and diesel generation, help transmission companies regulate their increasingly volatile systems, and hasten the adoption of electric vehicles. 'As the business develops, it is going to represent a game changer for the power sector,' said Jim Burpee, CEO at the Canadian Electricity Association." [The Globe and Mail, February 20, 2013]
}

These buzzwords not only suggested then-current industry perceptions of ES but will likely continue to inform public views of storage technologies and increase awareness of a changing energy landscape in Canada.

\section{Discussion}

Based on the results presented above, we identify the following findings related to ES discourse in each province. First, although discussions appear to be more prominent in Ontario than in Alberta, the salience of ES has shifted in both provinces since 2007. Climate change pressures and political mandates have spawned urgency 
for ES deployment, a topic which now extends beyond technical circles and into public discourse around economics, policy, culture, and the environment. Second, despite provincial-level variation in benefit and risk framing of storage, a higher frequency of positive rather than negative framing of ES in both provinces indicates a generally optimistic technological perspective in Canadian news media. Third, there appears to be a greater and more favourable media focus on smaller-scale, high-profile ES applications (e.g. batteries, fuel cells), while interpretations of other important ES technologies are absent or minimal (e.g. power-to-gas, solar-to-fuels). Fourth, our analysis shows that ES often appears in broader media discussion on sustainable development and innovation as an enabling component of cross-scalar, low-carbon energy transitions. Together, these findings reveal how provincial socio-political heritages and regional narratives might be informing public perception of new energy technologies, and more importantly, how these dynamics may impact future sustainable energy outcomes. We expand on the implications of these findings below.

\subsection{Prominence and frequency of ES discussions}

Despite some difference in provincial news circulation and population size, our results indicate greater and more positive ES media coverage in Ontario overall, which reflects the province's leadership in ES technology and recent regulatory development [7]. Nonetheless, the "rise then fall" temporal trend in media coverage in both provinces (see Figure 1) suggests that to some extent, public interest in ES over time conforms to Downs' "issue-attention cycle" [30]. This framework argues that society's attention to new issues occurs in a cyclical fashion, often due to contextual factors. Publics often demonstrate a sudden 'attention' to certain topics (e.g. energy developments) and hold such interest for a length of time until there is a realization of the cost associated with progress related to the issue, or new developments intervene to cause a gradual decline in interest [30]. This trend continues to be observed with issues related to climate change and sustainable development [67].

In an ES context, our findings suggest that provincial policy and regulatory changes may act as possible drivers for heightened public interest on the issue, hence leading to "peaks" in media coverage on storage development over time. Possible drivers for increased national coverage on ES in 2009 and 2016, for instance, might include various legislative changes, growing grid reliability concerns, and heightened national efforts to meet international climate change targets following the 2015 Paris Climate Change Accord. Although further research would help to identify causal factors in this regard, a similar pattern of public attention to new clean energy technologies has 
been observed with smart grid development in North America [34, 36].

\subsection{SPEED framing of ES}

A prevalence of economic and technological framing of ES in Canadian newspapers aligns with other SPEED studies on emerging technologies in North America (e.g. smart meters in the U.S) [25, 36]. However, it differs from discourse on more established innovations, such as CCS and wind turbines, which tend to see more cultural and environmental-risk media framing [35, 41, 68]. A greater economic and technical focus on ES in our media sample appears to be linked to the various usecases for storage across sectors, as well as its potential for improving multiple aspects of existing electricity systems (beyond merely providing additional energy generation).

Similarly, low political framing in our sample aligns with Langheim et al.'s [36] smart grid SPEED analysis, while differing from assessments on CCS, biofuels, and wind turbines, which tend to attract greater political media attention [35, 69]. Still, coverage in both provinces recognized gaps in policy planning for ES, advocating specifically for greater focus on asset optimization, system integration, and sociotechnical connectivity in energy system design. Ontario, for instance, recognizes the potential for ES to help reconcile socio-political tensions related to provincial energy issues by supporting new benefits and opportunities for energy stakeholders (e.g. improved electricity services, on-site generation). SPEED framing in both provinces also recognized the potential of ES on a broader, cross-sectoral scale. Long-term, ES is generally anticipated to help enable 'smarter' and more sustainable energy ecosystems comprised of distributed and renewable energy resources, transportation and waste management services, urban infrastructure, industrial design and community engagement [The Edmonton Journal, July 11, 2017; The Toronto Star, March 28, 2017].

Overall, provincial SPEED framing was relatively consistent with each jurisdiction's local energy contexts and anticipated motivations for ES. For instance, a higher frequency of economic benefit framing in Ontario reflected the province's advancing clean technology market, while a higher number of economic risk-oriented articles in Alberta suggested persistent provincial market and financial barriers. Coverage in both provinces also focused heavily on the environmental benefits of ES, which often overlapped with other SPEED frames (e.g. political, economic). The overlap and prevalence of these frames suggests that environmental benefits of ES are increasingly aligning with provincial policy and economic development goals (e.g. 
reduced reliance on fossil fuel generation).

Still, variance in prevalent SPEED frames suggest interprovincial differences in socio-political acceptance of ES, as well as unique priorities for future ES deployment. For instance, Ontario's top SPEED frames included economic, technical, and political categories, reflecting the province's interest in using ES to advance renewables, manage surplus baseload generation, and support clean technology sectors [16]. A high number of politically-framed articles in Ontario also reflect a history of government intervention in the province's electricity market. This heritage will have important sociopolitical implications for the fate of Ontario's energy industry, particularly as technology and market developments continue to rely on government support [28]. In contrast, Alberta's top SPEED frames included economic, technical, and environmental categories, suggesting a particular interest in the provincial economy, security, and climate change issues. Accordingly, SPEED framing suggested that ES drivers in Alberta include improving grid connectivity, ensuring greater resiliency for remote communities, and decarbonising the province's fossil fuel economy.

\subsection{Types and frequency of mentioned ES technologies}

Media discussions around specific storage technologies provided additional insight on public perceptions of ES. Media coverage in both provinces focused more on high-profile innovations such as Tesla's battery 'Powerpacks' and fuel cells, potentially due to their relationship with a greening transportation sector [The Globe and Mail, October 5, 2015]. Accordingly, there was considerably less mention of other technologies which could have equal if not more potential for influencing energy system change. Gallo et al. [1], for example, suggest that large-scale seasonal storage technologies such as power-to-gas, power-to-liquid, and solar-to-fuels offer promising attributes in this context, as they score best in emission tests and generate products that can help replace fossil fuels (e.g. natural gas). However, only one Alberta article recognized that compressed air or natural gas storage has underestimated potential [The Edmonton Journal, December 8, 2014].

Prevailing conversations on novel storage technologies suggests limitations in public awareness of and engagement with different ES applications, as high-profile technologies may not be the best suited for existing circumstances. Should this trend continue, future public acceptance of storage may become limited or skewed in favour of highly marketed storage applications, which could ultimately support the deployment of some ES technologies over others, regardless of varying suitability for different 
jurisdictions and system contexts. This discrepancy highlights the same socio-political complexity that Langheim et al. [36] identified with smart grid systems. Similar to the smart grid case, the breadth of ES technologies serves as both an asset and limitation. The range of ES functions and their unique interactions with different actors, market and regulatory factors can create ambiguity and bias in public framing of certain storage applications and their potential as energy transition tools [36].

\subsection{ES narratives, buzzwords and shifting discourse}

In addition to changes in frequency of ES discussions, we believe that the narratives used to discuss storage, and the changes in provincial benefit-to-risk framing ratios per year from 2007 to 2016 (i.e., later discourse containing more benefits and less risks) indicate a shift in public attitude toward storage in media coverage during this time. This shift in perception might have been influenced by emerging energy industry and policy developments such as Ontario's ES targeted procurements and a stronger push for coal divestment by Alberta's New Democratic Party (NDP) [The Globe and Mail, August 8, 2017; The Toronto Star, September 25, 2015]. For example, while some earlier Alberta editorials (e.g. 2007-2010) identified ES as part of an "overhyped green trend" embraced by left-wing economists [The Edmonton Journal, July 7 , 2007; The Calgary Herald, May 11, 2010], later discourse (i.e. 2013-2015) contained greater public support for diversifying Alberta's energy economy and supporting clean technology development. This progression was also apparent in Ontario coverage, albeit with more nuanced discussions on ES policy and regulatory development, as well as equity, ownership and operational structure debates within a transition context (e.g. utilities vs. government "driving the change").

While our results suggest greater prevalence and acceptance of ES in Ontario, media coverage also reflected Alberta's growing commitment to decarbonisation and interest in ES development as a technical energy solution. With the province's more supportive NDP government, increases in funding and R\&D initiatives, Canada's "fossil fuel powerhouse" may soon no longer lag behind Ontario on the path to a low-carbon energy future. Certainly, one of Alberta's greatest advantages is its ability to use Ontario's energy history to identify best practices and risks, evaluate solutions, and learn from past mistakes. One article from The Toronto Star summarizes how Ontario's leadership may influence Alberta's deployment of clean energy technologies:

"In some ways, Alberta will have it easier than Ontario did 10 years ago. The cost of wind and solar today are much more competitively priced, with costs having fallen so much over 
the past decade that subsidies - beyond a price on carbon - are unnecessary. Alberta also has the benefit of learning from the failures and successes of other jurisdictions that have made the transition and the province is eager to shed its reputation as an environmental laggard as the climate action imperative grows stronger. On the other hand, Ontario was less dependent on coal and had the benefit of hydroelectric and nuclear generation assets that Alberta lacks" [The Toronto Star, September 25, 2015].

In the coming decade, as ES costs decline, and market and legal frameworks for storage expand across Canada [10,13], more provinces will join Alberta and Ontario in deploying grid-scale ES. As this trend continues, provinces will need to carefully consider the evolving socio-political dynamics that both reflect and inform energy system change and integrate them in energy transition strategies accordingly. As demonstrated by our SPEED-media analysis, these dynamics can be analysed through public conversations in news media, which can provide insight on the pace and direction of regional electricity system change $[25,36]$.

\section{Conclusion}

ES is becoming a keystone technology for advancing low carbon energy transitions internationally. In Canada, Alberta and Ontario are leading jurisdictions in ES development, yet both provinces face unique opportunities and barriers for storage deployment. As Canadian provinces continue to respond differently to an evolving national energy landscape, social acceptance (e.g. community, market, socio-political) [39] will be essential for shifting ES from 'innovation niches' (e.g. R\&D phases) and into broader energy regimes [19, 21, 23]. To begin to understand how public acceptance and regional contexts might influence this transition process, we conducted a comparative SPEED media analysis of top-circulating newspapers reporting on ES in Alberta and Ontario between 2007 and 2017.

We found a greater socio-political acceptance of ES in Ontario, yet a relatively optimistic perspective on storage in Canadian media, overall. In both jurisdictions, SPEED framing and issue salience of ES appears to coincide with changing sociopolitical factors such as energy policy and regulatory improvements, R\&D and market activities, energy resource use and project installations. A prevalence of sustainable development-related narratives (e.g. climate change, transitions), and wide use of exaggerated buzzwords (e.g. missing link, holy grail) to describe ES (particularly in Ontario), also suggest a general confidence in the media that ES will play a key role in Canada's decarbonising energy sector. 
Still, perceived risks and tensions around ES development (e.g. cost, impact on fossil fuel industries) in newspapers suggest some public uncertainty around ES in certain provinces. While further mixed-methods research could offer direct causal insights among these factors, our analysis suggests that public framing of ES in Canadian newspapers is linked to regional narratives and local energy contexts. Together, these socio-political factors will likely influence the pace and direction of ES deployment across jurisdictions, within and outside of Canada.

Our findings thus present new research avenues and important lessons for other countries with fragmented energy markets and governance systems (e.g. Indonesia, United Kingdom) [72-73]. First, our results align with other energy studies which demonstrate the need for greater consideration of regional socio-political contexts in energy policy and project planning [49, 50,69]. Regional news media will continue to serve as key stakeholders in this process, as public framing can help decision-makers and practitioners better align emerging technology deployments with local concerns and expectations [56, 73]. Responding to regional public framing of storage with strategic communication, local consultation, and policy design, could help smooth technology deployment efforts [35, 43]. Failure to consider public framing, however, could hinder social acceptance of emerging technologies and create "system failures" in broader socio-technical transition processes [21, 23, 43].

Second, our findings suggest opportunities for future research on how social acceptance and deployment of ES might be informed by public views of highlymarketed or familiar technologies. A greater media focus (in both provinces) on smallscale, higher-profile ES technologies (e.g. batteries, fuel cells) over conventional bulkgrid systems (e.g. pumped hydro) indicates a skewed public knowledge and bias of existing ES applications and their varying suitability for specific contexts. This is important, as future ES deployment and innovation could be shaped by the marketing and positive or negative outcomes of high-profile projects and technologies.

Proponents may thus wish to incorporate public risk and benefit framing of trending technologies in deployment strategies to help generate favourable social perceptions of less recognized ES technologies (which may prove more effective in a transition context) [1]. Community information sessions, targeted media campaigns and local demonstration projects could allow publics to engage with diverse ES technologies more directly, and thus better understand their potential use-cases and benefits. 
Thirdly, we found that, to some extent, ES news discourse in Canada conforms to Downs' [30] 'issue-attention cycle' and could potentially fall into Gartner's 'Hype Cycle' [68] (should inadequate ES outcomes disappoint stakeholder expectations). The continuation of these trends could have important implications for public trust in and acceptance of ES deployments. ES developers and policymakers can capitalize on these 'windows of opportunity' [21] by taking advantage of public interest peaks or 'hypes' to foster more deliberative citizen engagement or timely implementation of ES policies, programs and projects [29]. Further research on this finding will help ascertain how temporal and discursive media patterns can be used to seize regional energy transition opportunities.

Finally, our approach can be easily adapted to various sub-national levels within and beyond a Canadian context, as researchers begin to investigate the interrelations between socio-political factors and ES deployment across various scales (e.g. household, community, municipality, state). To further understand ES in a transition context [1, 21, 23], we encourage the use of framing, narrative and other discourse analyses for contextualizing complex social interrelations that shape new energy developments [34]. Comparative media assessments, public surveys and case studies will be particularly useful for gauging how key stakeholders conceptually and rhetorically situate ES in local contexts, as well as for ascertaining the extent to which public discourse directly informs storage deployment.

\subsection{Appendix}

\subsection{Coding schemes}

\begin{tabular}{|c|l|l|}
\hline SPEED Frame & \multicolumn{1}{|c|}{ Benefit } & \multicolumn{1}{c|}{ Risk } \\
\hline Technical & $\begin{array}{l}\text { Engineering advancements; } \\
\text { technical change and } \\
\text { developments; interactions to } \\
\text { create new opportunities }\end{array}$ & $\begin{array}{l}\text { Potential negative technical aspects of } \\
\text { system change; interaction of } \\
\text { technologies to create new risks; needs } \\
\text { or vulnerabilities }\end{array}$ \\
\hline Economic & $\begin{array}{l}\text { Strengthening the economy } \\
\text { (jobs, manufacturing); saving } \\
\text { money; creating economic } \\
\text { opportunity across the system }\end{array}$ & $\begin{array}{l}\text { Increased costs to different actors; } \\
\text { increased economic uncertainty or } \\
\text { financial risk }\end{array}$ \\
\hline Political & $\begin{array}{l}\text { Positive political ramifications, } \\
\text { such as energy independence, } \\
\text { enhanced national security, } \\
\text { energy security, improved } \\
\text { reputation of a state or region } \\
\text { from system improvements }\end{array}$ & $\begin{array}{l}\text { Negative political ramifications, such as } \\
\text { public frustrations, and difficult legal } \\
\text { and regulatory processes from system } \\
\text { changes }\end{array}$ \\
\hline
\end{tabular}




\begin{tabular}{|c|l|l|}
\hline $\begin{array}{c}\text { Regulatory and } \\
\text { Legal }\end{array}$ & $\begin{array}{l}\text { Progress toward policy goals; } \\
\text { effectiveness of legal } \\
\text { framework to enhance system } \\
\text { function }\end{array}$ & $\begin{array}{l}\text { Frustrating, difficult, or deadlocked } \\
\text { legal and regulatory processes stalling } \\
\text { or derailing system change }\end{array}$ \\
\hline Environmental & $\begin{array}{l}\text { Reduced GHGs or carbon } \\
\text { emissions; mitigation of and } \\
\text { adaption to climate change; } \\
\text { energy conservation; less air } \\
\text { and water pollution; improved } \\
\text { environmental and public } \\
\text { health }\end{array}$ & $\begin{array}{l}\text { Potential threat to human or ecological } \\
\text { health, such as threats to protected } \\
\text { species and habitat destruction or } \\
\text { disruption; shifting risks to new } \\
\text { environmental areas }\end{array}$ \\
\hline Cultural & $\begin{array}{l}\text { Community pride; positive } \\
\text { behavioral change }\end{array}$ & $\begin{array}{l}\text { Concerns of privacy; aesthetics; } \\
\text { loss of control; inequality; perceived } \\
\text { negative impacts on way of life }\end{array}$ \\
\hline
\end{tabular}

Table A.1 The SPEED Framework. The enhanced SPEED Framework applied to smart grid deployment in the United States from Stephens et al. [25]

\begin{tabular}{|c|c|}
\hline Narrative & Criteria and examples \\
\hline Transportation & $\begin{array}{l}\text { - Corresponding SPEED frames: Environmental and technical } \\
\text { - Context: Article discusses ES in relation to transportation and } \\
\text { relevant technology and infrastructure; e.g. opportunities for new } \\
\text { rail transit services and other transportation improvements } \\
\text { - Key words and phrases: transportation, transit, drive, driving, } \\
\text { automobiles, cars, electric vehicles, fuel cells, charging stations, } \\
\text { rail, infrastructure } \\
\text { - Example: "That's where ABB's system comes in. Using a wayside, } \\
\text { or "beside-the-train-track," energy storage solution, the system } \\
\text { detects when a train is braking, and the voltage is rising, } \\
\text { automatically taking that energy flow into an 800-kilowatt lithium-ion } \\
\text { battery, or sending it back out when it detects another train } \\
\text { accelerating. If there isn't a need for the extra power stored, it can } \\
\text { be sold back to the wholesale energy market, or the grid." } \\
\text { [Edmonton Journal, July 11, 2013] }\end{array}$ \\
\hline $\begin{array}{l}\text { Community } \\
\text { development and } \\
\text { infrastructure }\end{array}$ & $\begin{array}{l}\text { - Corresponding SPEED frames: Cultural and economic } \\
\text { - Context: Article discusses ES in relation to community and urban } \\
\text { planning, city infrastructure development, physical changes to } \\
\text { community or other settings where people live; e.g. local ES } \\
\text { projects fostering new community engagement and leadership in } \\
\text { energy development } \\
\text { Key words and phrases: Community, community-based, } \\
\text { community-energy, community development, community planning, } \\
\text { neighbourhood, municipality, homes/houses, citizens, residents, } \\
\text { engagement, local, program, project } \\
\text { - Example: "Drake Landing is a solar-powered community where } \\
\text { thermal energy from sunlight is collected through solar panels } \\
\text { mounted on garage roofs and transferred to underground storage }\end{array}$ \\
\hline
\end{tabular}




\begin{tabular}{|c|c|}
\hline & $\begin{array}{l}\text { for use in homes in winter months. It's a collection of } 52 \text { homes and } \\
\text { is North America's first large-scale seasonal storage solar system." } \\
\text { [Calgary Herald, August 29, 2007] }\end{array}$ \\
\hline $\begin{array}{l}\text { R\&D and } \\
\text { technological } \\
\text { innovation }\end{array}$ & $\begin{array}{l}\text { - Corresponding SPEED frames: technical and economic } \\
\text { - Context: Article discusses ES in relation R\&D, technological } \\
\text { progress and improvements, ongoing research programs and } \\
\text { competitions; e.g. ES as a symbol of emerging innovation in } \\
\text { provincial energy sectors } \\
\text { Key words and phrases: innovation, innovative, new } \\
\text { technology/service, technological progress/development, cutting- } \\
\text { edge, solutions, grid modernization, funding, leadership, research, } \\
\text { system improvements, advance(ment), break-through } \\
\text { - Example: "I've seen significant market pull for the solutions that } \\
\text { that we have implemented in Ontario everything from Hydrostor's } \\
\text { innovative underwater storage (Chile is interested) to Temporal } \\
\text { Power's flywheels (solving challenges related to renewables } \\
\text { integration in Aruba) to Survalent's Advanced Management } \\
\text { Systems (already deployed in hundreds of utility customers around } \\
\text { the world). Innovation is hard. Leading is hard. And sometimes it is } \\
\text { messy." [The Hamilton Spectator, January 18, 2016] }\end{array}$ \\
\hline $\begin{array}{l}\text { Policy and } \\
\text { governance }\end{array}$ & $\begin{array}{l}\text { - Corresponding SPEED frames: political and legal/regulatory } \\
\text { - Context: Article discusses ES in relation to policy objectives, } \\
\text { interests, agendas and developments; legislation, regulations, laws } \\
\text { and frameworks; e.g. need for stronger policy frameworks to } \\
\text { support ES deployment } \\
\text { Key words and phrases: policy, legal, regulatory and/or policy } \\
\text { framework, political, government, governance, decision making, } \\
\text { programming, public sector, provincial policy strategy or plan } \\
\text { - Example: "There is no policy or programming developed around } \\
\text { energy storage in Ontario," says Lynda O'Malley, projects analyst at } \\
\text { the Centennial Energy Institute. O'Malley is part of a newly formed } \\
\text { group called the Energy Storage Leadership Group trying to } \\
\text { champion the cause. The group plans to come out with a position } \\
\text { paper in April that will recommend what policy and regulatory } \\
\text { changes will be needed to kick-start more experimentation and } \\
\text { eventually commercial deployment of energy-storage technologies } \\
\text { in the province." [The Toronto Star, January 14, 2011] }\end{array}$ \\
\hline $\begin{array}{l}\text { Energy transitions } \\
\text { and system } \\
\text { change }\end{array}$ & $\begin{array}{l}\text { - Corresponding SPEED frames: environmental, technical and } \\
\text { economic } \\
\text { - Context: Article discusses ES in relation to anticipated or ongoing } \\
\text { energy transformation or some sort of system change; transition to } \\
\text { low-carbon economy; e.g. ES as critical technology for advancing } \\
\text { clean energy transition } \\
\text { - Key words and phrases: (low-carbon or clean energy) transition, } \\
\text { transformation, system change, alternations, reform, restructur(ing), } \\
\text { energy change, revolution, evolution, evolving industry, reform, }\end{array}$ \\
\hline
\end{tabular}




\begin{tabular}{|c|c|}
\hline & $\begin{array}{l}\text { restructure, improve(ment), change(s), energiewende, progress } \\
\text { - Example: “Toronto could take it and store it as hydrogen and use it } \\
\text { to reduce electricity costs at peak times in Toronto. It would set us } \\
\text { up to be in a position to even out the peaks and valleys in energy } \\
\text { production in the province and test-drive the infrastructure needed } \\
\text { to transition completely to green energy." [The Toronto Star, } \\
\text { January } 14,2011 \text { ] }\end{array}$ \\
\hline $\begin{array}{l}\text { Climate change } \\
\text { mitigation and } \\
\text { decarbonisation }\end{array}$ & $\begin{array}{l}\text { - Corresponding SPEED frames: environmental and economic } \\
\text { - Context: Article discusses ES in relation to decarbonisation goals } \\
\text { and targets; the elimination of fossil fuels for economic and/or } \\
\text { environmental reasons; reducing environmental impacts and } \\
\text { enabling sustainable development; e.g. ES to help offset carbon } \\
\text { emissions produced from fossil fuels } \\
\text { - Key words and phrases: climate change, decarbonisation, fossil } \\
\text { fuel phase-out or divestment, cut or offset carbon emissions, } \\
\text { reduce environmental impacts, ecological, environment(al), } \\
\text { sustainability, sustainable development, clean electricity or } \\
\text { economy, low-carbon society } \\
\text { - Example: "It's not commercial to adopt all of these measures yet, } \\
\text { but a lot of hard work is being done, so that five, } 10 \text { years from now } \\
\text { we'll be able to lower our emissions and our environmental impact } \\
\text { significantly." [Calgary Herald, June 5, 2007] }\end{array}$ \\
\hline $\begin{array}{l}\text { Economic growth } \\
\text { and development }\end{array}$ & $\begin{array}{l}\text { - Corresponding SPEED frames: economic } \\
\text { - Context: Article discusses ES in relation to the economy, finance, } \\
\text { market and other forms of development; investment and } \\
\text { commercial opportunities; competiveness in energy market; e.g. ES } \\
\text { development creating new job opportunities } \\
\text { - Key words and phrases: economic development, economic } \\
\text { growth, clean technology sector, jobs, employment, economy, } \\
\text { investment opportunities, revenue potential, cost savings, economic } \\
\text { benefits, dollar, price(s) } \\
\text { - Example: "We feel energy storage is the missing link," she told a } \\
\text { seminar organized by York University's Sustainable Energy } \\
\text { Initiative. "Large-scale storage is a multi-billion-dollar opportunity } \\
\text { that would benefit Canada and the world, and we are going for it," } \\
\text { said Verschuren, who is backed by Northwater Capital." [The } \\
\text { Toronto Star, September 22, 2012] }\end{array}$ \\
\hline
\end{tabular}

Table A.2. Narrative analysis coding framework. Narrative coding criteria, key words and excerpts from articles assigned to specific narratives.

\section{References}

[1] A.B. Gallo, J.R. Simões-Moreira, H.K.M Costa, M.M Santos, E. Moutinho dos Santos, Energy Storage in the Energy Transition Context: A Technology Review, Renewable and Sustainable Energy Reviews, 65 (2016) 800-822. DOl: 


\section{$\underline{10.1016 / j . r s e r .2016 .07 .028}$}

[2] Gulagi, D. Bogdanov, C. Breyer, The demand for storage technologies in energy transition pathways towards $100 \%$ renewable energy for India, Energy Procedia, 135 (2017) 37-50. DOI:10.1016/j.egypro.2017.09.485

[3] N. Good, E.A.M. Ceseña, E. A. M., C. Heltorp, P. Mancarella, A transactive energy modelling and assessment framework for demand response business cases in smart distributed multi-energy systems, Energy, (2018) [In Press]

DOI:10.1016/j.energy.2018.02.089

[4] C.F. Heuberger, I. Staffell, N. Shah, N. Mac Dowell, A systems approach to quantifying the value of power generation and energy storage technologies in future electricity networks, Computers \& Chemical Engineering, 107 (2017) 247-256. DOI: 10.1016/j.compchemeng.2017.05.012

[5] K. Vaillancourt, O. Bahn, E. Frenette, O Sigvaldason, Exploring deep decarbonization pathways to 2050 for Canada using an optimization energy model framework, Applied Energy, 195 (2017) 774-785.

[6] M. Yazdanie, M. Densing, A. Wokaun, The role of decentralized generation and storage technologies in future energy systems planning for a rural agglomeration in Switzerland, Energy Policy, 96 (2016) 432-445. DOI: 10.1016/i.enpol.2016.06.010

[7] P. Devine-Wright, S. Batel, O. Aas, B. Sovacool, M.C. Labelle, A. Ruud. A Conceptual Framework for Understanding the Social Acceptance of Energy Infrastructure: Insights from energy storage, Energy Policy, 107 (2017) 27-31. DOI: $\underline{10.1016 / j . e n p o l .2017 .04 .020}$

[8] A.S. Sidhu, M.G. Pollitt, K.L Anaya, A social cost benefit analysis of grid-scale electrical energy storage projects: A case study, Applied Energy, 212 (2018) 881-894. DOI: 10.1016/j.apenergy.2017.12.085

[9] H. Chen, T.N. Chong, W. Yang, C. Tan, Y. Li, and Y. Ding. Progress in electrical energy storage system: A critical review, Progress in Natural Science, 19 (2009) 291312. DOI: 10.1016/j.pnsc.2008.07.014

[10] Navigant Research, Country Forecasts for Utility-Scale and Distributed Energy Storage Reports. https://www.navigantresearch.com/newsroom/global-annual-powercapacity-additions-for-utility-scale-and-distributed-energy-storage-to-exceed-50-gw-by$\underline{2026}, 2017$ (accessed 20 July 2017).

[11] McKiney \& Company, McKinsey on Sustainability and Resource Productivity. [Report]. United States: McKinsey \& Company. [Report] (No. 4), https://www.mckinsey.com/ /media/McKinsey/Business\%20Functions/Sustainability\%2 0and\%20Resource\%20Productivity/Our\%20Insights/McKinsey\%20on\%20Sustainabilit y\%20and\%20Resource\%20Productivity\%20Number\%204/McKinsey\%20on\%20Sustai nability\%20and\%20Resource\%20Productivity\%20lssue\%204.ashx, 2016 (accessed 20 July 2017).

[12] U.S. Department of Energy (DOE), Global Energy Storage Database, Office of Electricity Delivery and Energy Reliability. http://www.energystorageexchange.org/projects, 2018 (accessed 1 August 2017). 
[13] P. Sommerville, R. Carlson, P. Prazic. Emerging Energy Trends: Regulatory Responses to Ontario's Energy Future. [Report] (No. \#141). Toronto: Mowat Research. https://mowatcentre.ca/emerging-energy-trends-report/, 2016 (accessed 31 May 2017)

[14] A. Eller, D. Gauntlett. Energy Storage Trends and Opportunities in Emerging Markets. [Report]. Colorado, U.S: Navigant Consulting Inc., https://www.ifc.org/wps/wcm/connect/ed6f9f7f-f197-4915-8ab6-56b92d50865d/7151IFC-EnergyStorage-report.pdf, 2017 (Accessed June 5 2017)

[15] A. Tuck, Q. Wang, K. Malek. Y. Grinburg, F. Bensebaa. Canadian Energy Storage Roadmap. [Report]. Toronto, Canada: National Research Council Canada. http://doi.org/10.4224/23001380, 2017 (accessed 5 June 2017)

[16] Government of Ontario, Ontario's Long-Term Energy Plan 2017: Delivering Fairness and Choice, [Report] (ISBN 978-1-4868-0735-2). Ottawa, Canada: Ministry of Energy, https://files.ontario.ca/books//tep2017 0.pdf, 2017 (Accessed April 3 2018)

[17] International Energy Agency (IEA), Technology Road Map: Energy Storage. [Report]. Paris, France: OECD/IEA.

https://www.iea.org/publications/freepublications/publication/TechnologyRoadmapEner gystorage.pdf, 2014 (accessed 22 June 2017)

[18] T.J. Foxon, Transition pathways for a UK low carbon electricity future, Energy Policy, 52 (2013) 10-24.

[19] S.O Negro, F. Alkemade, M.P. Hekkert, Why Does Renewable Energy Diffuse So Slowly? A Review of Innovation System Problems, Renewable and Sustainable Energy Reviews, 16 (2012) 3836-3846. DOI: 10.1016/j.rser.2012.03.043

[20] C. Miller, A., lles, C.F. Jones, The social dimensions of energy transitions. Science as Culture, 22 (2013) 135-148. DOI:10.1080/09505431.2013.786989

[21] F.W. Geels, Typology of sociotechnical transition pathways. Research Policy, 36 (2007) 399-417. DOl:10.1016/j.respol.2007.01.003

[22] S. Muench, S. Thuss, E. Guenther, What Hampers Energy System Transformations? The Case of Smart Grids, Energy Policy, 73 (2014) 80-92. DOl: 10.1016/j.enpol.2014.05.051

[23] F.W. Geels The Multi-Level Perspective on Sustainability Transitions: Responses to Seven Criticisms. Environmental Innovation and Societal Transitions, 1 (2009) 2440. DOI:10.1080/09505431.2013.786989

[24] B.K. Sovacool, What are we doing here? Analyzing fifteen years of energy scholarship and proposing a social science research agenda, Energy Research \& Social Science, 1 (2014) 1-29. DOI: 10.1016/j.erss.2014.02.003

[25] J.C. Stephens, T.R. Peterson, E.J. Wilson. Socio-Political Evaluation of Energy Deployment (SPEED): A framework applied to smart grid, UCLA Law Reviews, 61 (2014) 1930-1961.

[26] C.A Miller, J. Richter, J. O'Leary, Socio-energy systems design: A policy framework for energy transitions, Energy Research \& Social Science, 6 (2015) 29-40. DOI:10.1016/j.erss.2014.11.004 
[27] J. Chilvers, T.J. Foxon, S. Galloway, G.P. Hammond, D. Infield, M. Leach ... \& M. Thomson, Realising transition pathways for a more electric, low-carbon energy system in the United Kingdom: Challenges, insights and opportunities. Proceedings of the Institution of Mechanical Engineers, Part A, Journal of Power and Energy, 231 (2017) 440-477. DOI: 10.1177/0957650917695448

[28] J. Meadowcroft, J.C. Stephens, E.J. Wilson and I.H. Rowlands. Social dimensions of smart grid: Regional analysis in Canada and the United States. Introduction to special issue of Renewable and Sustainable Energy Reviews, Renewable and Sustainable Energy Reviews [In Press, Corrected Proof], DOI: $\underline{10.1016 / j . r s e r .2017 .06 .106}$

[29] A. Mallett, M. Jegen, X.D. Philion, R. Reiber, D. Rosenbloom, Smart grid framing through coverage in the Canadian media: Technologies coupled with experiences. Renewable and Sustainable Energy Reviews, 82 (2017) 1952-1960. DOI: $\underline{10.1016 / j . r s e r .2017 .06 .013}$

[30] A. Downs, The issue-attention cycle and the political economy of improving our environment, The Political Economy of Environmental Control. Berkley, California, United States: University of California Press, 1972.

[31] N. Luhmann, The Reality of The Mass Media, Stanford, California, United States: Stanford University Press, 2000.

[32] W.A Gamson, A Modigliani, Media discourse and public opinion on nuclear power: A constructionist approach, American Journal of Sociology, 95 (1989) 1-37. DOI: $\underline{10.1086 / 229213}$

[33] J.I. Scrase, D.G. Ockwell, The role of discourse and linguistic framing effects in sustaining high carbon energy policy-an accessible introduction, Energy Policy, 38 (2010) 2225-33. DOI: 10.1016/j.enpol.2009.12.010

[34] J.C. Stephens, E.J. Wilson, T.R. Peterson, Socio-Political Evaluation of Energy Deployment (SPEED): An integrated research framework analyzing energy technology deployment, Technological forecasting and social change, 75 (2008) 1224-1246. DOI: 10.1016/j.techfore.2007.12.003

[35] A.M. Feldpausch-Parker, M. Burnham, M. Melnik, M.L Callaghan, T. Selfa, News media analysis of carbon capture and storage and biomass: Perceptions and possibilities, Energies, 8 (2015) 3058-3074. DOI: 10.3390/en8043058

[36] R. Langheim, M. Skubel, X. Chen, W. Maxwell, T.R. Peterson, E. Wilson, J.C. Stephens, Smart Grid Coverage in U.S. Newspapers: Characterizing public conversations, The Electricity Journal, 27 (2014) 77-87. DOI: 10.1016/j.tej.2014.05.008

[37] N. Dusyk, J. Axsen, K. Dullemond, Who cares about climate change? The mass media and socio-political acceptance of Canada's oil sands and Northern Gateway Pipeline, Energy Research \& Social Science, 37 (2017) 12-21. DOI: 10.1016/j.erss.2017.07.005

[38] P.G. Taylor, R. Bolton, D. Stone, P. Upham, Developing pathways for energy storage in the UK using a coevolutionary framework, Energy Policy, 63 (2013) 230 243. DOI: 10.1016/j.enpol.2013.08.070 
[39] R. Wüstenhagen, M. Wolsink, M.J. Bürer, Social acceptance of renewable energy innovation: An introduction to the concept, Energy Policy, 35 (2007) 2683-2691. DOI: 10.1016/j.enpol.2006.12.001

[40] S. Batel, P. Devine-Wright, T. Tangeland. Social acceptance of low carbon energy and associated infrastructures: A critical discussion, Energy Policy, 58 (2013) 1-5.

DOI: 10.1016/j.enpol.2013.03.018

[41] Y. Fournis, M.J. Fortin, From social 'acceptance' to social 'acceptability' of wind energy projects: Towards a territorial perspective, Journal of Environmental Planning and Management, 1 (2017) 1-24. DOI: 10.1080/09640568.2015.1133406

[42] J. Rotmans, R. Kemp, M. Van Asselt, More evolution than revolution: Transition management in public policy, Foresight, 3 (2001) 15-31. DOI:

$\underline{10.1108 / 14636680110803003}$

[43] P.H. Grünewald, T.T. Cockerill, M. Contestabile P.J.G. Pearson, The SocioTechnical Transition of Distributed Electricity Storage into Future Networks: System Value and Stakeholder Views, Energy Policy, 50 (2012) 449-457. DOI: 10.1016/j.enpol.2012.07.041

[44] P.O. Pineau, Fragmented markets: Canadian electricity sectors' underperformance, Evolution of Global Electricity Markets, 1 (2013) 363-392. https://doi.org/10.1016/B978-0-12-397891-2.00013-4

[45] Government of Canada, National Energy Board: Market Snapshot: Batteries Dominate Early Stage Testing for Energy Storage in Canada. https://www.nebone.gc.ca/nrg/ntgrtd/mrkt/snpsht/2016/07-03bttrsdmnttstngeng.html?=undefined\&wbdisable=true, 2016 (accessed 3 April 2018).

[46] J. Meadowcroft, What about the politics? Sustainable development, transition management, and long term energy transitions, Policy Sciences, 42 (2009) 323-340. DOI: $10.1007 / \mathrm{s} 11077-009-9097-\mathrm{z}$

[47] M. Lowey, Energy Storage Market Growing Rapidly but Big Hurdles Remain in Alberta. http://www.envirolinenews.ca/news-analysis/news/2017/02/22/energy-storagemarket-growing-rapidly-but-bighurdles-remain-in-albertal, 2017, (accessed 5 June 2017).

[48] Alberta Storage Alliance (ASA), Energy Storage: Unlocking the value for Alberta's grid. [White Paper]. http://albertastoragealliance.com/white-paper/, 2016 (accessed 5 June 2017).

[49] M. Winfield, The ultimate horizontal issue: The environmental policy experiences of Alberta and Ontario, 1971-1993, Canadian Journal of Political Science/Revue canadienne de science politique, 27 (1994) 129-152. DOI: $\underline{10.1017 / S 0008423900006247}$

[50 M. Winfield, B. Dolter, Energy, economic and environmental discourses and their policy impact: The case of Ontario' s Green Energy and Green Economy Act, Energy Policy, 68 (2014) 423-435. DOI: 10.1016/j.enpol.2014.01.039

[51] T. Daniel, J. Doucet, A. Plourde, Electricity industry restructuring: The Alberta experience. Electric Choices: Deregulation and the Future of Electric Power. [Working Paper]. Edmonton, Canada: University of Alberta, 91-111. 
https://www.ualberta.ca/business/-

/media/business/centres/cabree/documents/thealbertaexperience.pdf, 2001, (accessed 28 March 2018).

[52] D.B. Richardson, L.D. Harvey, Optimizing renewable energy, demand response and energy storage to replace conventional fuels in Ontario, Canada, Energy, 93 (2015) 1447-1455. DOI: 10.1016/j.energy.2015.10.025

[53] Government of Canada, National Energy Board: Provincial and Territorial Energy Profiles - Alberta. https://www.neb-one.gc.ca/nrg/ntgrtd/mrkt/nrgsstmprfls/ab-eng.html, 2016 (accessed 3 April 2018).

[54] Independent Electricity System Operator (IESO), IESO Report: Energy Storage. [Report]. Toronto, Canada: IESO. http://www.ieso.ca/corporateieso/media/publications, 2016 (Accessed 23 June 2017).

[55] P. Upham, C. Oltra, À. Boso, Towards a cross-paradigmatic framework of the social acceptance of energy systems, Energy Research \& Social Science, 8 (2015) 100-112. DOI: 10.1016/j.erss.2015.05.003

56] Government of Canada, National Energy Board: Provincial and Territorial Energy Profiles - Ontario. https://www.neb-one.gc.ca/nrg/ntgrtd/mrkt/nrgsstmprfls/on-eng.html, 2016 (accessed 3 April 2018).

[57] B.E. Deignan, B. Harvey, L. Hoffman-Goetz. Fright Factors About Wind Turbines and Health in Ontario Newspapers Before and After the Green Energy Act, Health, Risk \& Society, 15 (2013) 234-250. DOI: 10.1080/13698575.2013.776015

[58] [dataset] News Media Canada data for 2015 daily newspaper circulation in Canada, https://nmc-mic.ca/about-newspapers/circulation/daily-newspapers/, 2015 (accessed 1 June 2017).

[59] World Population Review, Canada Population 2018 http://worldpopulationreview.com/countries/canada-population/cities/, 2018 (accessed 1 April 2018).

[60] I. Iskin, R.A. Taha, T.U. Daim, Exploring the adoption of alternative energy technologies: A literature review, International Journal of Sustainable Society, 5 (2013) 43-61. DOI: 10.1504/IJSSOC.2013.050534

[61] J.R. Macnamara, Media content analysis: Its uses, benefits and best practice methodology, Asia-Pacific Public Relations Journal, 6 (2005) 1-34.

[62] J. Iggers, Good news, bad news: Journalism ethics and the public interest. New York City, New York, United States: Routledge, 2018.

[63] Y. Zhou, P. Moy, Parsing framing processes: The interplay between online public opinion and media coverage, Journal of Communication, 57 (2007) 79-98. DOI: 10.1111/j.1460-2466.2006.00330.x

[64] M. Nilsson, The Missing Link: Bringing institutions and politics into energy future studies, Futures, 43 (2011) 1117-1128. DOI: 10.1016/j.futures.2011.07.010 
[65] A. Schmidt, A. Ivanova, M.S. Schäfer. Media attention for climate change around the world: A comparative analysis of newspaper coverage in 27 countries, Global Environmental Change, 23 (2013) 1233-1248.

[66] G. Richards, B. Noble, K. Belcher, Barriers to renewable energy development: a case study of large-scale wind energy in Saskatchewan, Canada, Energy Policy, 42 (2012) 691-698. DOI: 10.1016/j.enpol.2011.12.049

[67] W. Wright, T. Reid, Green dreams or pipe dreams?: Media framing of the US biofuels movement, Biomass and Bioenergy, 35 (2011) 1390-1399. DOl: $\underline{10.1016 / \text { j.biombioe. } 2010.07 .020}$

[68] O. Dedehayir, M. Steinert, The hype cycle model: A review and future directions, Technological Forecasting and Social Change, 108 (2016) 28-41. DOl: 10.1016/j.techfore.2016.04.005

[69] P. Devine-Wright, Public engagement with large-scale renewable energy technologies: Breaking the cycle of NIMBYism, Wiley Interdisciplinary Reviews: Climate Change, 2 (2011) 19-26. DOI: 10.1002/wcc.89

[70] A. Goldthau, Rethinking the governance of energy infrastructure: Scale, decentralization and polycentrism, Energy Research \& Social Science, 1 (2014) 134140. DOI: 10.1016/j.erss.2014.02.009

[72] M. Thomas, G Ellis, Subnational governance for the low carbon energy transition: Mapping the UK's 'Energy Constitution', Environment and Planning C: Government and Policy, 35 (2017) 1176-1197. DOI: 10.1177/2399654416687999

[73] H. Shin, B.D. Choi, Risk perceptions in UK climate change and energy policy narratives, Journal of Environmental Policy \& Planning, 17 (2015) 84-107. DOI: $\underline{10.1080 / 1523908 X .2014 .906301}$ 